\title{
Postaci czołowych działaczy białoruskich w świetle informacji Urzędu Komisarza Rządu na miasto Wilno w 1924 roku
}

Zarys treści: W spuściźnie Komisarza Rządu na miasto Wilno Autorka opracowania odnalazła opinie dotyczące piętnastu działaczy białoruskich (nie tylko wileńskich): Wsiewołoda Bildziukiewicza, Klaudiusza Duż-Duszewskiego, Fabiana Jeremicza, Michała Kochanowicza, Arseniusza Konczewskiego, Michała Krasińskiego, Józefa Łohinowicza, Antona Łuckiewicza, Józefa Mamońki, Radosława Ostrowskiego, Michała i Franciszka Pietkiewiczów, Bazylego Rahuli [Raguli], Szymona Rak-Michajłowskiego i Włodzimierza Samojło. Dodana jest informacja o wspierającym ruch białoruski w Wilnie Żydzie, [Borysie] Kleckinie.

Outline of content: The legacy of the Delegate of the Government in Vilnius the author has found opinions about fifteen Belarusian activists, operating not only in Vilnius: Vsevolod Bildziukiewicz, Klaudiusz Duż-Duszewski, Fabian Jeremicz, Michał Kochanowicz, Arseniusz Konczewski, Michał Krasiński, Józef Łohinowicz, Anton Luckevitch, Jazep Mamonka, Radosław Ostrowski, Michał and Franciszek Pietkiewicz, Basil Rahulia [Ragulia], Szymon Rak-Michajłowski and Włodzimierz Samojło. This is supplemented by the information about the Jew [Boris] Kleckin, who supported the Belarusian movement in Vilnius.

Słowa kluczowe: I Zjazd Wszechbiałoruski (grudzień 1917), Ziemie Wschodnie, Ziemia Wileńska 1922-1925, województwo wileńskie, bezpieczeństwo publiczne 1918-1939, działacze białoruscy

Keywords: I All-Belarusian Congress (December 1917), Eastern Lands, Vilnius Land 1922-1925, Vilnius Voivodeship, public security 1918-1939, Belarusian activists

W na terenie Ziemi Wileńskiej, powierzonej w latach 1922-1925 pieczy Delegata Rządu ${ }^{1}$, znajdowało się najwięcej - po Nowogródczyźnie - skupisk ludności biało-

1 Komisarzami Rządu byli kolejno: Władysław Sołtan, Walery Roman (od 6.04.1922 do 29.08.1924); Władysław Raczkiewicz; Olgierd Malinowski. Zob. też: ustawa z 22.12.1925 r. w sprawie utworzenia województwa wileńskiego Dz.U., 1926, nr 6, poz. 29; http://isap.sejm.gov.pl/DetailsServlet?id= 
ruskiej na terytorium Państwa Polskiego. Dokładne ustalenie procentowego udziału Białorusinów wśród mieszkańców Wileńszczyzny i pozostałych ziem wschodnich jest niemożliwe, co wynika $\mathrm{z}$ jednej strony $\mathrm{z}$ braku wykrystalizowanej świadomości narodowej i niezakończonego procesu kształtowania się języka białoruskiego w chwili przeprowadzania spisu ludności 30 września 1921 r., a z drugiej - z przyjętych w trakcie tego spisu kryteriów.

Nie bez znaczenia jest też fakt, iż pod koniec 1922 r. na konferencji w Wilnie zapadła decyzja o rozszerzeniu działalności Komunistycznej Partii Robotniczej Polski (KPRP) o Wilno i Grodno², a wiosną 1923 r. utworzono Obwód Litewsko-Białoruski KPRP. W październiku 1923 r. ostatecznie powstała Komunistyczna Partia Zachodniej Białorusi. II Zjazd KPRP uznał negowane dotąd prawo narodów do samookreślenia, co spowodowało zakwestionowanie przez tę partię ówczesnej wschodniej granicy Polski ${ }^{3}$. Hasła KPRP padały na coraz podatniejszy grunt na wsi białoruskiej. Nastroje panujące wśród wileńskich liderów mniejszości białoruskiej w sposób oczywisty stały się przedmiotem zainteresowania organów bezpieczeństwa państwa polskiego.

Autor podstawowej pracy o historii Policji Państwowej II RP, Andrzej Misiuk ustalił ${ }^{4}$ że Policja Polityczna w dwudziestoleciu była trzykrotnie gruntownie reorganizowana, a jej działalność można podzielić na cztery okresy przypadające na lata: 1919-1923, 1923-1924, 1924-1926 i 1926-19395. Czas sprawowania funkcji Delegata Rządu w Wilnie przez Walerego Romana przypadał na drugi z wyodrębnionych przez A. Misiuka okresów, który zapoczątkowany został 26 kwietnia 1923 r., a zakończony - 27 maja 1924 r. Władysław Sikorski (łączący w kwietniu $1923 \mathrm{r}$. funkcję premiera $\mathrm{z}$ obowiązkami ministra spraw wewnętrznych) powołał wówczas podległą organom administracji politycznej Służbę Informacyjną. Funkcję kierownika Oddziału Informacyjnego w Departamencie Bezpieczeństwa Publicznego MSW pełnił Marian Swolkień. Podległy mu Oddział Informacyjny w latach 1923-24 składał się z dwóch działów, a w skład drugiego z nich wchodził szereg referatów - między innymi referat białoruski'

Na szczeblu województwa kompetencje wojewódzkich oddziałów informacyjnych uzyskały okręgowe urzędy policji politycznej utworzone przy komendach okręgowych Policji Państwowej (PP). Według przytaczanych przez A. Misiuka zestawień sporządzonych w czerwcu 1925 r., czyli na pół roku przed utworzeniem

WDU19260060029 (dostęp: 6.12.2014).Wcześniej na tym terenie obowiązywała Ustawa o objęciu władzy państwowej nad Ziemią Wileńską, Dz.U., 1922, nr 26, poz. 213; http://isap.sejm.gov.pl/ DetailsServlet?id=WDU19220260213 (dostęp: 6.12.2014).

${ }^{2}$ H. Cimek, Białorusini w ruchu rewolucyjnym w II Rzeczypospolitej, w: Kwestia narodowościowa w Polsce $i$ we Włoszech w XX wieku. Wybrane problemy, red. H. Cimek, Rzeszów 2011, s. 184.

${ }^{3}$ Komunistyczna Partia Zachodniej Białorusi powstała jako autonomiczna organizacja obwodowa KPRP z połączenia grup komunistów z Białegostoku, Brześcia, Grodna i Wilna.

4 A. Misiuk, Policja Państwowa 1919-1939, Warszawa 1996, s. 371.

${ }^{5}$ Szerzej: ibidem, s. 252-253 i dalsze.

${ }^{6}$ Całą strukturę wnikliwie omawia A. Misiuk, zob.: ibidem, s. 251-287. 
województwa wileńskiego, w Okręgu XVI Wileńskim PP zatrudnionych było 65 funkcjonariuszy ${ }^{7}$. Według danych z 1926 r. w okręgu wileńskim działało sześć ekspozytur policji politycznej. Z braku danych trudno ocenić liczebność okręgowej placówki wileńskiej na przełomie lat 1923 i 1924, ale można przyjąć, że była to w okręgu wileńskim ekspozytura najliczniejsza.

Oddział Informacyjny miał zbierać i analizować materiały informacyjne otrzymywane od organów terenowych. W swojej pracy policjanci stosowali różne metody, wydaje się jednak, że w latach 1923-1924 koncentrowali się przede wszystkim na wywiadzie konfidencjonalnym. W efekcie referat białoruski uzyskał z Wilna bardzo dużo ciekawych informacji biograficznych na temat postaci ruchu białoruskiego, przy czym dotyczyły one - co zaskakujące - głównie okresu do 1919 r., a nie lat 1920-1924. Należy wyraźnie podkreślić, że odnalezione przeze mnie opinie o znaczących białoruskich działaczach politycznych nie tylko rozszerzają obecny stan wiedzy o jednostkowych losach ich bohaterów, ale zawierają także niesłychanie ciekawe i poznawcze elementy charakterystyki bardziej i mniej znanych osób. To, że dla współczesnych historyków informacje pozyskane w roku 1924 przez Służbę Informacyjną stanowią bogate źródło wiedzy, nie zmienia faktu, iż z punktu widzenia osób odpowiedzialnych wtedy za bezpieczeństwo państwa efekty pracy agentów nie spełniły pokładanych w nich nadziei. W konsekwencji w maju 1924 r. służbę tę zlikwidowano, a na jej miejsce powołano pion Policji Politycznej ${ }^{8}$. Wileńscy pracownicy tej ostatniej rekrutowali się $\mathrm{w}$ większości $\mathrm{z}$ byłych funkcjonariuszy Agentury Informacyjnej i korzystali z plonu swojej pracy z okresu poprzedniego. Dlatego nazwy policja polityczna i Agentura (Agencja) Informacyjna w odniesieniu do prezentowanych źródeł można właściwie używać zamiennie.

$\mathrm{Na}$ podstawie informacji zawartych $\mathrm{w}$ dokumentach wytworzonych przez Agenturę Informacyjną przy wileńskim XVI Okręgu Policji Państwowej oraz w oparciu o komentarze ich autorów można $\mathrm{z}$ całą pewnością wygenerować „obraz ruchu białoruskiego w oczach Polaków w Wilnie na przełomie 1923 i 1924 r." oraz wydedukować, jakie było nastawienie wileńskich władz administracyjnych do miejscowych liderów białoruskich.

W specyficznej sytuacji politycznej panującej na ziemiach północno-wschodnich w latach 1923-1924 jest rzeczą zrozumiałą, iż Departament Bezpieczeństwa

7 Ibidem, s. 273.

8 Przepisy o organizacji centrali Policji Politycznej (Wydziału V KG PP) zostały ogłoszone 1 lipca 1924 r., a kierownikiem Wydziału V, podzielonego na dwa człony, pozostał Marian Swolkień. Obok członu informacyjnego podlegał mu człon tzw. przestępczości, składający się z szeregu referatów - m.in. komunistyczno-wywrotowego (był to czas głośnych wystąpień antypolskich na ziemiach północno-wschodnich) oraz białorusko-litewskiego.

9 Patrz: Walka instytucji państwowych z białoruska działalnościa dywersyjna 1920-1925, wybór i oprac. W. Śleszyński. Białystok 2005, s. 182. Ostatnio o sytuacji tej i jej genezie pisał P. Cichoracki, 
(Oddział Informacyjny) Ministerstwa Spraw Wewnętrznych w Warszawie jeszcze jesienią 1923 r. wystosował do Delegata Rządu w Wilnie zapytanie na temat czołowych wileńskich działaczy białoruskich. W spuściźnie Delegata Rządu w Wilnie odnalazłam 15 opinii, które w odpowiedzi na to pismo sporządzono pomiędzy grudniem 1923 r. a czerwcem 1924 r. $^{10}$

Dotyczyły one Białorusinów, których nazwiska wymieniam w kolejności alfabetycznej, a byli to: Wsiewołod Bildziukiewicz, Klaudiusz Duż-Duszewski, Fabian Jeremicz, Michał Kochanowicz, Arseniusz Konczewski, Michał Krasiński, Józef Łohinowicz, Anton Łuckiewicz, Józef Mamońko, Radosław Ostrowski, Franciszek Pietkiewicz, Michał Pietkiewicz, Bazyli Rahula [Ragula], Szymon Rak-Michajłowski i Włodzimierz Samojło. Dodana jest też informacja o wspierającym ruch białoruski Żydzie, [Borysie] Kleckinie.

Jak wynika $\mathrm{z}$ tego zestawienia, nie wszyscy aktywni w tym czasie Białorusini wileńscy zostali scharakteryzowani przez pracowników placówki wileńskiej ${ }^{11}$.

Stołpce-Łowcza-Leśna 1924: II Rzeczpospolita wobec najpoważniejszych incydentów zbrojnych w województwach pótnocno-wschodnich, Łomianki 2012 (tu obszerna literatura tematu).

10 Lietuvos Centrinis Valstybes Archivas (dalej: LCVA), fond 51 (Urząd Wojewódzki Wileński), ap. 17, byla 6. Kleckin a Białorusini l.V 4376/24/V, lap. 1; Łuckiewicz Antoni, lap. 11-11v (Urząd Komisarza Rządu na m. Wilno L.dz. 1419/I/24/Ag.inf, Wilno, 7.03.1924, Do Oddziału Informacyjnego w.m. Charakterystyka Łuckiewicza); Pietkiewicz Franciszek, lap. 13. (Urząd Komisarza Rządu na m. Wilno L.dz. 3973/I/24/Ag.inf, Wilno, 3.06.1924. Do Oddziału Informacyjnego w.m. Pietkiewicz Franciszek. Informacje [Podp. M. Olendzki]); Pietkiewicz Michał, lap. 14 (Urząd Komisarza Rządu na m. Wilno L.dz. 2079/I/24/Ag.inf, Wilno, 4.04.1924. Do Oddziału Informacyjnego w.m. Pietkiewicz Michał. Informacje [Podp. M. Olendzki, kierownik Agent. Inf.]); Ostrowski Radosław, lap. 15-15v (Charakterystyka Radosława Ostrowskiego); Samojło Włodzimierz, lap. 16-16v (Urząd Komisarza Rządu na m. Wilno L.dz. 2078/I/24/Ag.inf, Wilno, 4.04.1924. Do Oddziału Informacyjnego w. m. Samojło Włodzimierz. Opinia [Podp. M. Olendzki, kierownik Agent. Inf.]); Bildziukiewicz Wsiewołod, lap. 18 (Urząd Komisarza Rządu na m. Wilno L.dz. 2080/I/24/Ag.inf, Wilno, 4.04.1924. Do Oddziału Informacyjnego w.m. Bildziukiewicz Wsiewołod. Opinia [Podp. M. Olendzki, kierownik Agent. Inf.]); Łohinowicz Józef, lap. 20-20v (Urząd Komisarza Rządu na m. Wilno L.dz. 2077/I/24/Ag.inf, Wilno, 4.04.1924. Do Oddziału Informacyjnego w.m. Łohinowicz Józef. Opinia [Podp. M. Olendzki, kierownik Agent. Inf.]); Konczewski Arseniusz, lap. 22 (Urząd Komisarza Rządu na m. Wilno L.dz. 2077/I/24/Ag.inf, Wilno, 4.04.1924. Do Oddziału Informacyjnego w.m. Konczewski. Opinia [Podp. M. Olendzki, kierownik Agent. Inf.]); Kochanowicz Michał, lap. 24; Jeremicz Fabjan, lap. 25-25v-26; Ragula Bazyli, lap. 27-27v-28; Duż-Duszewski Klaudiusz, lap. 29-29v; Michał Krasiński, lap. 30-31; Szymon Rak-Michajłowski, lap. 32-33.

${ }^{11}$ Wg ustaleń policji w skład Dzielnicowego Komitetu Socjalrewolucjonistów (SR) w Wilnie w lecie 1923 r. wchodzili, oprócz Łuckiewicza i Łohinowicza, Ławrynowicz, Swietogor, Stepom, Rodziewicz, Szyło, Łapin, Drucki-Podberski, Miotła, Listopad, Budkiewicz, Eugeniusz Jużyk vel Iwżyk, Sapak-Sapaczyński, Szymański, Ejsmontt i Lidia Ustinowicz. Do Białoruskiej Centralnej Rady Szkolnej (siedziba Wilno, Wileńska 12) wchodzili Trepko i Żawryd. W skład Rady Towarzystwa Szkoły Białoruskiej („Szkoła”) oprócz Rak-Michajłowskiego, Łuckiewicza, Taraszkiewicza, Kochanowicza, Konczewskiego, ks. Stankiewicza, Pietkiewicza i Łohinowicza wchodzili Bogdanowicz, Kotowicz, Mankiewicz, Sokołowa, Gieniaszij, Budźko, Kunicki i Poczopko. 
Jednocześnie scharakteryzowano również takich, o których wiemy, że opuścili Wilno przed 1923 rokiem $^{12}$.

Styl wypowiedzi i sposób argumentacji, a także oceny poszczególnych wydarzeń politycznych i faktów podanych w odnalezionych charakterystykach wskazują, iż były one pisane przez kilku ludzi. Część opinii podpisywał za Komisarza Rządu Kierownik Agentury Informacyjnej Urzędu Komisarza Rządu, M. Olendzki. Część odnalezionych opinii jest niepodpisanymi przez nikogo „załącznikami”, do których listy przewodnie nie zostały odnalezione ${ }^{13}$.

Odnalezione informacje są $\mathrm{w}$ dziesięciu przypadkach rozbudowane i przynoszą wiele zadziwiająco precyzyjnych informacji (precyzyjnych nie oznacza ostatecznie potwierdzonych) dotyczących aktywności osób, którym są poświęcone, w okresie od początku wieku do 1919 r. Uważam, że wykorzystano w tych notatkach informacje uzyskane od Białorusinów, którzy z różnych pobudek współpracowali z Polakami. Jest przecież rzeczą nieprawdopodobną, by liczne szczegóły dotyczące np. wewnętrznego układu sił w Białoruskiej Centralnej Radzie Wojskowej w roku 1917, znane były komukolwiek oprócz obecnych tam działaczy białoruskich. Przyjmuję ponadto, że nie wszystkim informatorom przyświecała chęć uzyskania wyłącznie korzyści materialnych.

Powierzchowność i ogólnikowość informacji (lub wręcz brak informacji podstawowych) posiadanych przez pracowników Policji Politycznej w Wilnie na temat aktywności liderów białoruskich, i to zarówno w okresie istnienia Zarządu Cywilnego Ziem Wschodnich ${ }^{14}$ (dalej: ZCZW) jak i Litwy Środkowej, potwierdzają hipotezę o wykorzystaniu przez wileńską Służbę Informacyjną w zasadzie wyłącznie źródeł konfidencjonalnych. Najwyraźniej nie korzystano z dokumentacji sporządzonej przez organy administracyjne w latach wcześniejszych. Bez względu na przyczyny tego stanu rzeczy, luki wiedzy w kwestiach dotyczących wydarzeń i losów większości liderów białoruskich w latach 1919-1922 świadczą bądź o małej efektywności aparatu bezpieczeństwa wymienionych struktur policyjnych, bądź o niekompetencji urzędników agentury.

W trakcie lektury nasuwa się refleksja, że rozmówcy polskich agentów swobodnie udzielali informacji przede wszystkim o wydarzeniach sprzed 6-7 lat, kreśląc przy okazji profile psychologiczne wybranych działaczy białoruskich. Służyć to mogło do zneutralizowania bądź osłabienia pozycji politycznych adwersarzy (stąd informacje o ludziach znaczących, ale od dłuższego czasu już nieobecnych

12 Pomiędzy 13 a 25 czerwca 1923 r. doszło do ostrego konfliktu pomiędzy ówczesnym Dyrektorem Białoruskiego Gimnazjum a całym podległym mu personelem. Poseł Kochanowicz na stałe wyjechał do Baranowicz. Klaudiusz Duż-Duszewski od roku 1921 mieszkał i pracował w Kownie.

${ }^{13}$ LCVA, fond 51, ap. 17, byla 6: Kochanowicz Michał, lap. 24; Jeremicz Fabjan, lap. 25-25v-26; Ragula Bazyli, lap. 27-27v-28; Duż-Duszewski Klaudiusz, lap. 29-29v; Michał Krasiński, lap. 30-31; Szymon Rak-Michajłowski, lap. 32-33.

${ }^{14}$ O ZCZW zob. J. Gierowska-Kałłaur, Zarząd Cywilny Ziem Wschodnich 19 lutego 1919 - 9 września 1920, Warszawa 2003, s. 447. 
w Wilnie). Zaskakująca jest też konstatacja, iż współpracujący z Polakami Białorusini nie wiedzieli prawie nic o swoim pierwszoplanowym działaczu, jakim bez wątpienia był Anton Łuckiewicz ${ }^{15}$. Trudno rozstrzygnąć po latach, czy był to efekt autocenzury konfidentów, ich nieświadomości, czy też tego - czego wykluczyć nie można - że działali po prostu na zlecenie Antona Łuckiewicza ${ }^{16}$. Podkreślam - pozostaje pytaniem badawczym to, czy współpracujący z polskimi władzami Białorusini nic nie wiedzieli o większości istotnych faktów z lat 1920-1924 (co wydaje się mało prawdopodobne), czy też uznali za niewskazane informowanie o niektórych z nich polskich „współpracowników” ze Służby Informacyjnej przy Okręgu XVI Wileńskim Policji Państwowej.

$\mathrm{W}$ tekście tego artykułu występuje bardzo dużo nazwisk Białorusinów z reguły całkowicie nieznanych czytelnikowi polskiemu, co skutkuje koniecznością sporządzenia licznych i obszernych przypisów osobowych. I tutaj mamy kłopot. To, co o tych ludziach wiemy, jest efektem pracy wielu autorów, z reguły historyków białoruskich. Pomimo ich wysiłków nie są to biogramy pełne. Na stronie polskiego Sejmu widzimy dziś (grudzień 2014) apel z prośbą o nadsyłanie danych takich, jak np. informacje o dacie i miejscu śmierci białoruskiego senatora Wiaczesława Bohdanowicza i innych ${ }^{17}$. Uważam, że na obecnym etapie badań nie jesteśmy w stanie rzetelnie skreślić ostatecznych biogramów wielu z tych postaci, a złożyło się na ten stan rzeczy bardzo wiele czynników. Stan wiedzy poszczególnych autorów na temat losów liderów białoruskich jest różny. Informatorzy z reguły byli Białorusinami i o ile mi wiadomo - wyznawali prawosławie, co w niektórych przypadkach może mieć znaczenie. Rozbieżności między nimi występują nie tylko w zakresie faktograficznym, ale nawet w kwestii prawidłowej pisowni nazwisk. W zamieszczonych przypisach biograficznych sygnalizuję, skąd zaczerpnęłam konkretne informacje opublikowane przez: Aleksandrę Bergman (Sprawy białoruskie w II Rzeczypospolitej,

15 Anton Łuckiewicz (1884-1942), zob. przyp. 52.

${ }^{16}$ Według danych, które podaje Ewidencja wybitniejszych osób pracujacych w organizacjach politycznych, społecznych, zwiazkach zawodowych, kooperatywach i organizacjach zawodowych w mieście Wilnie, w czasie kampanii wyborczej do Sejmu I kadencji w Warszawie Radosław Ostrowski przy pomocy Józefa Mitkiewicza nawiązał poufny kontakt z Antonem Łuckiewiczem i również poufnie popierał Blok Mniejszości Narodowościowych, chociaż oficjalnie utrzymywał kontakt z „Zielonym Dębem”, występując rzekomo jako przeciwnik Wileńskiego Białoruskiego Komitetu Narodowego. Obszerna informacja dotycząca Radosława Ostrowskiego z roku 1926, stanowiąca wypis $\mathrm{z}$ tej ewidencji, przechowywana jest Archiwum Akt Nowych (dalej: AAN), MWRiOP, sygn. 1062, s. 375-382.

17 Wiaczesław Bohdanowicz, Вячаслаў Васілевіч Багдановіч (1878-1941?) - działacz związany z Cerkwią prawosławną, absolwent Duchownej Akademii Prawosławnej w Kijowie; od 1907 inspektor Prawosławnego Duchowego Seminarium w Wilnie, a potem jego rektor. W 1917 był delegatem na Wielki Sobór Cerkiewny w Moskwie; był założycielem Białoruskiego Prawosławnego Zjednoczenia, od 1922 senator, od 1920 członek Białoruskiego Komitetu Narodowego w Wilnie; przeciwnik autokefalii białoruskiej cerkwi prawosławnej; więzień Berezy Kartuskiej. W październiku 1939 aresztowany przez NKWD. Jego dalszy los nie jest znany; DM2, przyp. 277; http:// pl.wikipedia.org/wiki/Wiaczes\%C5\%82aw_Bogdanowicz (dostęp: 6.12.2014). 
Warszawa $1984=\mathrm{AB}$ ), Krystynę Gomółkę (Białorusini w II Rzeczypospolitej, Gdańsk 1992 = KG), Olega Łatyszonka (Białoruskie formacje wojskowe 1917-1923, Białystok 1995 = OŁ), Andreja Czarniakiewicza (А. Чарнякевіч, Постаці беларускага начьыянальнага руху ў Гродне 1909-1939: біяграфбічны даведнік, Мінск $2003=$ ACz), Eugeniusza Mironowicza (Białoruś, Warszawa $1999=$ EM1; wyd. 2: 2007 = EM2). Próbę podsumowania tych ustaleń podjęła w $2006 \mathrm{r}$. Dorota Michaluk (Jestem przyjacielem Białorusinów - raporty wywiadowcze Romualda Ziemkiewicza do II Oddziału Sztabu Generalnego WP $z$ lat 1922-1923, oprac. D. Michaluk, „Białoruskie Zeszyty Historyczne” z. 25 (2006), s. 209-258 [= DM1]) i z. 26 (2006), s. 236-280 [= DM2]). Należałoby tu wymienić jeszcze wiele innych nazwisk.

Pozostaje kwestia tzw. praw autorskich (lub odpowiedzialności za przekłamania). Osobiście uważam, iż treść króciutkich notek obejmujących informacje takie jak daty życia, pełnione funkcje polityczne i społeczne nie wymaga odwołań bibliograficznych, ale już opracowane przez Andreja Czarniakiewicza biogramy 16 postaci występujących w tekście - jak najbardziej ich wymagają.

W dobie powszechnej krytyki źródeł internetowych chciałabym zwrócić uwagę na jedno źródło - obecnie powszechnie dyskredytowane. Chcę wyrazić uznanie dla licznego grona Białorusinów wolontariuszy, którzy wpisując do Wikipedii ${ }^{18}$ białoruskie hasła oraz ich uzupełnienia, usiłują nieść „kaganek oświaty” swoim pobratymcom na Białorusi. Tam, jak wiadomo, nie ma tak szerokiego dostępu do wiedzy i takiej wolności słowa, jakie są obecnie w Polsce. Postanowiłam więc przywoływać w przypisach biograficznych te hasła, które na to zasługują, tym bardziej że z reguły zawierają one odnośniki do wciąż uzupełnianej bibliografii, jak też linki do interesujących stron internetowych.

Jak już napisano, osoby zatrudnione w Agencji Informacyjnej przy Okręgu XVI Wileńskim Policji Państwowej w dużym stopniu oparły się w swojej pracy na informacjach konfidentów. Na temat wiarygodności takiego źródła można toczyć długie, akademickie spory. Ja sama uważam, że raporty, które powstały w oparciu o to źródło, w sposób wiarygodny odzwierciedlają stan wiedzy ich autorów. Uzyskane informacje pozwalają na rekonstrukcję procesów decyzyjnych w omawianej epoce historycznej.

Tekst umowy zawartej w Mińsku 17 marca 1923 r. (dalej: Umowa Mińska) pomiędzy przebywającymi na terytorium Litwy przedstawicielami białoruskich socjalrewolucjonistów, socjaldemokratów i socjalfederacjonistów, a pełnomocnikami Białoruskiej SSR był znany polskiej Policji Politycznej stosunkowo wcześnie ${ }^{19}$.

${ }^{18}$ Według mojej wiedzy hasła białoruskie zamieszczane na łamach Wikipedii są uzupełniane na bieżąco.

19 Komenda Policji Państwowej Okręgu XVI Wileńskiego Okręgowy Urząd Policji Politycznej, L.dz 8723/24/V Ściśle tajne. Zarys ruchu białoruskiego od czasów jego powstania aż po dzień deklaracji mińskiej z 1.03.1924. Zawiera obszerne fragmenty układu. Lietuvos Centrinis Valstybės Archyvas 
Umowa ta została poddana drobiazgowej analizie w powstałym w czerwcu $1924 \mathrm{r}$. Okręgowym Urzędzie Policji Politycznej Komendy Policji Państwowej Okręgu XVI Wileńskiego. Analiza, podpisana przez kierownika tej jednostki, M. Olendzkiego, w niekorzystnym dla Białorusinów świetle zarysowała perspektywę dalszych stosunków litewsko-białoruskich.

Umowa Mińska została zawarta pomiędzy Zmicierem Żyłunowiczem ${ }^{20}$ i Usiewaładem Ihnatouskim ${ }^{21}$ - pełnomocnikami Białoruskiej Socjalistycznej Sowieckiej Republiki - a Aleksandrem Gołowińskim ${ }^{22}$, Aleksandrem Walkowiczem ${ }^{23}$ i Gołubincewem, legitymującymi się pełnomocnictwami Białoruskiej Partii Socjalrewolucjonistów, Białoruskiej Partii Socjal-Demokratycznej oraz Białoruskiej Partii Socjalfederacjonistów. Umowa, której odpisem dysponowała strona polska, oczywiście była tajna ${ }^{24}$.

Obie zawierające ten układ strony liczyły na utrzymanie Litwinów w stanie niewiedzy co do faktu zawarcia umowy, tak by ci „mieli nadzieję, że w najbliższych

(Wilno), fond 51, ap. 17, lap. 5, k. 1-85. Ten sam dokument odnalazłam też w Archiwum Akt Nowych w Warszawie (w Zespole Policji Politycznej z Wilna, sygn. 7, k. 2-93). Dalej cytuję jako: „Zarys ruchu białoruskiego”. Noszę się z zamiarem wydania całości tego obszernego tekstu drukiem.

${ }^{20}$ Zmicier [Dymitr] Żyłunowicz, Зміцер Хведаравіч Жылуновіч; ps. Ciszka Hartny, Цішка Гартны (1887-1937) - pracownik Białoruskiego Komitetu Uciekinierów (1916); aktywista Białoruskiej Socjalistycznej Hromady (1917); sekretarz, przewodniczący i uczestnik I Zjazdu Wszechbiałoruskiego w Mińsku, w 1919 premier Białoruskiej Socjalistycznej Republiki Radzieckiej. Redaktor „Sowieckiej Białorusi” od 1920. W 1920 wszedł w skład Centralnego Komitetu Wykonawczego BSRR (kolegialnej głowy państwa). Dążył do nawiązania współpracy z lewicowym skrzydłem BRL (m.in. BPRS). Od 1927 do 1929 był zastępcą członka Komitetu Centralnego KP(b)B i WKP(b). W latach 1934-1936 był pracownikiem Instytutu Historii Białoruskiej Akademii Nauk. W 1936 aresztowany pod zarzutem działalności w „organizacjach kontrrewolucyjnych" i zamordowany przez NKWD w więzieniu; EM, s. 298; DM2, przyp. 243; http://pl.wikipedia.org/wiki/Zmicier_\%C5\%BBy\%C5\%82unowicz (dostęp: 6.12.2014).

${ }^{21}$ Usiewaład Ihnatouski, Усевалад Макаравіч Ігнатоўскі (1881-1931) - białoruski działacz narodowy, członek Hramady i KP(b)B, komisarz oświaty BSRR, dyrektor Instytutu Kultury Białoruskiej i pierwszy przewodniczący Akademii Nauk Białoruskiej SRR. Poparł powstanie Białoruskiej Socjalistycznej Republiki Radzieckiej zarówno w 1919, jak i w 1920, widząc w jej istnieniu szansę na częściowe urzeczywistnienie ideałów niepodległościowych. Od 1919 członek RKP(b) i KP(b) B, rok później mianowano go komisarzem oświaty. W latach 1922-1930 zasiadał w Centralnym Komitecie Wykonawczym BSRR. Od 1924 do 1926 kierował wydziałem agitacji i propagandy KC KP(b)B. W latach 20. wraz z Aleksandrem Czerwiakowem i Zmicierem Żyłunowiczem był zaangażowany w akcję ściągania $\mathrm{z}$ emigracji działaczy białoruskiego ruchu narodowego; http:// pl.wikipedia.org/wiki/Usiewa\%C5\%82ad_Ihnatouski (dostęp: 6.12.2014).

22 Alaksandar Gaławiński, Аляксандар Кузміч Галавінскі (1886-?) - członek delegacji rządu BRL wybranej 21.03.1919 na konferencję pokojową w Paryżu; od 1927 w BSRR, członek Inbiełkultu, pracownik naukowy Białoruskiej Akademii Nauk; OŁ; ACz, s. 65-66.

23 Alaksandr Walkowicz, Аляксандр Іванавіч Вальковіч (1892-1937) - członek Białoruskiej Partii Socjalistów-Rewolucjonistów, minister finansów Białoruskiej Republiki Ludowej (BRL), skazany na śmierć przez rozstrzelanie przez władze radzieckie.

${ }^{24}$ Rozdział XXII: „POROZUMIENIE SIĘ PRZEDSTAWICIELI RZĄDU Łastowskiego i lewicowych ugrupowań białoruskich z sowietami. Umowa mińska”, w: „Zarys ruchu białoruskiego”. 
dniach oswobodzimy Białoruś z Wilnem i połączymy ją z Litwąa". Przewidywano także, iż w przyszłości Sowieci żądać będą odwołania rządu Wacława Łastowskiego ${ }^{25}$. „Tymczasem będziemy żądali od nich skasowania i wysiedlenia $\mathrm{z}$ terenów Litwy rządu Łastowskiego. Może w tym wypadku będziemy musieli zwinąć przedstawicielstwo na Litwie, lecz odwróci to w zupełności uwagę od wszelkich podejrzeń, że jesteśmy w porozumieniu"26.

Utajnienie Umowy Mińskiej miało m.in. na celu dalsze egzekwowanie utrzymywania przez stronę litewską istniejącego w składzie armii litewskiej batalionu białoruskiego. Ponieważ sygnatariusze tego porozumienia nie przewidywali dalszego sprawowania funkcji premiera przez Wacława Łastowskiego, zamierzano na razie wykorzystać jego osobę dla zmylenia Litwinów ${ }^{27}$. Ustalenia dotyczyły również spraw obsady dowództwa oddziału białoruskiego - strona sowiecka postulowała zastąpienie porucznika Razumowicza - „człowieka ze starymi rosyjskimi tradycjami” - „człowiekiem bardziej odpowiednim”.

Ingerencje sygnatariuszy Umowy Mińskiej w sprawy obsady personalnej stanowisk Białoruskiej Republiki Ludowej ${ }^{28}$ sięgały jeszcze dalej. W miejsce premiera

25 Wacław Łastowski, Вацлаў Юстынавіч Ластоўскі, Vacłaŭ Łastoŭski (1883-1938) - białoruski publicysta i polityk, filolog, literaturoznawca, historyk, BSH (1906-1908); członek Wileńskiej Rady Białoruskiej (1918-1919), od kwietnia 1918 w Radzie BRL; przedstawiciel BRL w Tarybie Litewskiej; w Białoruskiej Partii Socjalistów-Rewolucjonistów od 1919; premier rządu Białoruskiej Republiki Ludowej w latach 1919-1923 (od 13.12.1919); następnie zatrudniony w Ministerstwie Spraw Białoruskich w Kownie; od kwietnia 1927 w BSRS; dyrektor Białoruskiego Muzeum Państwowego i kierownik Katedry Etnografii w Instytucie Kultury Białoruskiej (1927-1929); zwolniony (1929), aresztowany (1930) i zesłany do Saratowa, gdzie pracował w Dziale Rękopisów Uniwersytetu; 1938 aresztowany ponownie i rozstrzelany; ACz, s. 151-152; DM1, przyp. 96; http://pl.wikipedia.org/wiki/Wac\%C5\%82au_\%C5\%81astouski (dostęp: 6.12.2014).

26 „Zarys ruchu białoruskiego”.

27 „Istniejący batalion białoruski będzie kiedyś naszym; winien on być utrzymywany przez Litwinów, naszym zadaniem jest zrobienie $\mathrm{z}$ tych żołnierzy prawdziwych Białorusinów. Pieniądze na to powinny i będą dawane od nas z Mińska w takiej ilości jak tego wymaga sprawa i jak postanowi Komisariat Finansów łącznie z Centralnym Komitetem Komunistycznej Partii Białorusi”, ibidem.

${ }^{28}$ Białoruska Republika Ludowa (Беларуская Народная Рэспубліка, Biełaruskaja Narodnaja Respublika) - jej powstanie ogłosił Komitet Wykonawczy Rady I Kongresu Wszechbiałoruskiego 9 marca 1918 r. w Mińsku, w warunkach tymczasowej okupacji centralnej części ziem białoruskich przez wojska niemieckie. Iluzoryczną „niepodległość” - po burzliwych naradach przewagą jednego głosu - ogłoszono 25 marca tego roku. Z powodu braku powszechnego uznania międzynarodowego oraz braku własnego wojska, skarbu, administracji i niemożności sprawowania kontroli nad postulowanym terytorium, Białoruska Republika Ludowa nie posiadała ustalonych granic. 13 grudnia 1919 r. Białoruska Partia Socjalistów-Rewolucjonistów i Białoruska Partia Socjalistów-Federalistów dokonały swego rodzaju zamachu stanu. Od tego czasu funkcjonowało dwóch premierów. Pierwszym był dotychczasowy premier Anton Łuckiewicz, który powołał Najwyższą Radę BRL na czele $z$ Iwanem Sieredą. Nie jest prawdą, iż Łuckiewicz podał się do dymisji w lutym 1920 r. Osobiście widziałam w LCVA podpisane przez A. Łuckiewicza jako premiera dokumenty z lata 1920 r. O A. Łuckiewiczu jako o premierze - pisali jeszcze w pierwszym półroczu 1921 r. polscy dyplomaci z Paryża. Zamachowcy 13 grudnia 1919 r. utworzyli natomiast Ludową Radę BRL w nowym składzie na czele z Piotrem Kreczeuskim (Kreczeuskim) i nowy 
Wacława Łastowskiego, którego zamierzano w dalszej perspektywie zmusić do podania się do dymisji, proponowano kandydatury profesorów Lackiego lub Żytłowskiego, ewentualnie dr. Salomona Łurje ${ }^{29}$ lub Aleksandra Ćwikiewicza ${ }^{30}$. Dyrektywa płynąca ze strony sowieckiej była klarowna:

Wszyscy przedstawiciele Białorusi za granicą powinni prowadzić sprawy czysto polityczne, nie zajmując się zupełnie sprawami komunistycznymi, a w stosunku do bolszewików powinni być jak najgorzej usposobieni. Istniejący zaś rząd Łastowskiego, który jest uważany za rząd wrogi Białorusi Sowieckiej, powinien prowadzić swe prace nadal, dlatego rząd ten powinien zostać rządem w chwili obecnej, a to dla oka Zachodniej Europy. Co się tyczy samego Łastowskiego, to nie powinien on stać na czele tego rządu, ponieważ jest on człowiekiem za mało wykształconym, a następnie nie jest on zupełnie popularny w kołach dyplomatycznych Zachodniej Europy i dlatego trzeba go zastąpić człowiekiem więcej odpowiednim. Zrobić to trzeba w ten sposób, jak gdyby wewnątrz rządu wynikły nieporozumienia i Łastowski podał się sam do dymisji. Zaprosić na jego miejsce można profesora Lackiego lub Żytłowskiego, obecnie ministra mniejszości narodowych. A także nie będziemy nic przeciwko temu mieli, jeśli będzie zaangażowany doktor Lurje lub Ćwikiewicz ${ }^{31}$.

Wszystkie inne osoby miały pozostać nadal na swych stanowiskach. Łastowski zaś miał zająć stanowisko pozwalające mu na najczęstszy kontakt $z$ Litwinami, ponieważ nie uszło uwadze Moskwy, iż polityk ten cieszył się wśród nich dużą sympatią.

rząd na czele z Wacławem Łastowskim. Po rozpoczęciu negocjacji polsko-radzieckich (jesienią 1920 r.) w Mińsku rząd Łastowskiego 11 listopada 1920 r. podpisał w Kownie z władzami Litwy tajną umowę o współpracy polityczno-ekonomicznej w kwestii stworzenia w porozumieniu z narodami wschodniej Polski (przede wszystkim z Ukraińcami) jednego antypolskiego frontu; http:// pl.wikipedia.org/wiki/Bia\%C5\%82oruska_Republika_Ludowa (dostęp: 6.12.2014); zob. też pracę D. Michaluk, Białoruska Republika Ludowa...

${ }^{29}$ Salomon Łurje, Соломон Лурье (1890/1891-1964) - historyk starożytności, filolog, absolwent uniwersytetu w Petersburgu (1911), członek Rady Delegatów Robotniczych w Mohylewie (1917), wydawca gazety „Echo” i współpracownik Rządu BRL (1918), wykładowca akademicki uniwersytetu w Piotrogrodzie (1918), Samarze (1919-1920), Leningradzie (do 1949), doktor nauk historycznych (1934), doktor nauk filologicznych (1943), wykładowca uniwersytecki we Lwowie (1953-1964); DM2, przyp. 248.

30 Alaksandr Ćwikiewicz, Аляксандар Цьвікевіч (1888-1937/1938) - białoruski historyk i polityk, filozof i publicysta, absolwent prawa Uniwersytetu Petersburskiego (1912) - przysięgły sądowy w Brześciu i Prużanach, założyciel Białoruskiej Ludowej Hromady w Moskwie, w 1918 w składzie delegacji URL w Brześciu, w latach 1918-1920 skoncentrował się na działalności dyplomatycznej (misje w Kijowie, Moskwie i Berlinie), w latach 1921-1923 minister spraw zagranicznych BRL, w 1923 zastąpił Wacława Łastouskiego na stanowisku premiera Białorusi na wychodźstwie (z siedzibą w Pradze). Za centrum polityczne Białorusi uważał Mińsk; jako członek partii socjalno-rewolucyjnej optował za dialogiem z ZSRR, zwalczając „polską okupację” Białorusi; podczas berlińskiego spotkania przywódców emigracyjnych wypowiedział się za zaprzestaniem działalności władz BRL i uznaniem państwowości Białoruskiej SRR. Po podaniu się do dymisji (1925) wyjechał do BSRS; pracował w Instytucie Białoruskiej Kultury i Instytucie Historii Białoruskiej Akademii Nauk; w 1930 aresztowany i zesłany do Permu. Ponownie aresztowany w 1937 i rozstrzelany w Mińsku; DM2, przyp. 250.

31 „Zarys ruchu białoruskiego”. 
Zalecano, by wszyscy przedstawiciele Białorusi demonstrowali złe nastawienie do komunizmu. Bez ogródek mówiono o długoterminowym celu porozumienia: „Sprawy zagraniczne winny pójść nadal tą samą koleją, należy jedynie położyć specjalny nacisk, by państwa zachodnie patrzyły na tę sprawę nie jak na akcję bolszewicką, a jak na akcję narodowo-białoruską, jak gdyby rząd Łastowskiego nie miał nic wspólnego z bolszewikami i Mińskiem. W przeciwnym razie nie będziemy mogli uzyskać [uznania?] zagranicy, o co tak długo się dobijamy"32.

Umowa obejmowała też wytyczne do bieżącej taktyki. Ze względu na „chwilę zupełnego spokoju na zewnątrz" ustalono bezwzględne wstrzymanie - na razie planowanych powstań zbrojnych na terenie Polski, które mogłyby „popsuć jedynie sprawę". Zakładano, iż w korzystnym momencie (w razie nieuniknionej wojny) garstka białoruskich partyzantów znajdzie się na terenie Litwy i wesprze akcję armii sowieckiej. W sprawie rządu przyszłej niepodzielnej Białorusi pozostać miała w mocy umowa podpisana przez Łastowskiego w listopadzie 1919 r. w Mińsku.

Dobra wola i brak wyrobienia politycznego graniczący z niespotykaną łatwowiernością znaczącej i - niestety, jak się okazało - wpływowej grupy polityków białoruskich zostały wykorzystane przez stronę sowiecką.

Ocena sytuacji przez stronę polską była jasna. Czynnik białoruski potraktowany został instrumentalnie w planowanej przez Moskwę rozgrywce europejskiej.

Z punktu widzenia Kremla pierwszą flanką do zdobycia była Litwa i Polska.

Brak łączności pomiędzy Polską i Litwą sprawił, iż każdy z tych krajów na własną rękę starał się poradzić sobie $\mathrm{z}$ problemem zagrażającym bezpieczeństwu obu państw. Czujność Litwinów dodatkowo uśpił traktat litewsko-rosyjski zawarty w krytycznej dla Polski chwili - 12 lipca 1920 r. Zawarcie tego traktatu było brzemienne w skutki. O konsultacjach polsko-litewskich na przełomie 1923 i $1924 \mathrm{r}$. oczywiście nie mogło być mowy.

Sygnatariusze Umowy Mińskiej nie kryli, iż ich celem dalekosiężnym jest „odzyskanie zachodniej Białorusi od Polski”, co wymagało zarówno metodycznej pracy jak i środków finansowych, które miały być przekazywane w wysokości 15000 franków miesięcznie w charakterze subsydium dla rządu Łastowskiego. Pocztę przekazywać miano za pośrednictwem Kastusia Jezowitowa ${ }^{33}$ (przez Dźwińsk), Aleksandra

32 Ibidem.

${ }^{33}$ Konstantin Jezawitau, Канстанцін (Кастусь) Езавітаў, znany jako Kastuś Jezowitow (1893-1946) - kierownik wydziału formacji wojskowych Białoruskiej Centralnej Rady Wojskowej. W styczniu 1918 w celu zapobieżenia domniemanej aneksji terytorium przez oddziały Dowbor-Muśnickiego wezwał do formowania gwardii białoruskiej m.in. w Bobrujsku; w lutym 1918 był białoruskim komendantem miasta Mińska (obok polskiego); organizator oddziałów białoruskich w październiku 1918, w kwietniu-maju 1919 w Grodnie wykorzystywał antypolskie nastroje społeczności żydowskiej; przedstawiciel rządu BRL na Łotwie. O jego działalności w czasie II wojny światowej obszerniej pisze J. Grzybowski, Pogoń między Orłem Białym, Swastyką i Czerwonq Gwiazdą: białoruski ruch niepodległościowy w latach 1939-1956, Warszawa 2011; zob. też Dokument X, w: J. Gierowska-Kałłaur, „Studia z Dziejów Rosji i Europy Środkowo-Wschodniej” 47 (2012), s. 208-272, http://www.sdr-ihpan.edu.pl/files/10_gierowska.pdf. 
Czerwiakowa $^{34}$ (przez Rygę), Mikołę Wierszynina ${ }^{35}$ (przez Pragę), Borowskiego ${ }^{36}$ (przez Berlin), Mikołaja Szyłę, Eduarda Budźkę $e^{37}$ i Bronisława Taraszkiewicza ${ }^{38}$ (przez Warszawę i Wilno), Jakimowicza, Sergiusza Barana ${ }^{39}$ i Szymona Jakowiuka ${ }^{40}$ (przez Grodno) oraz Salomona Łurje ${ }^{41}$ i Dryjera (przez Gdańsk).

34 Aleksander Czerwiakow, Аляксандр Чарвякоў (1892-1937) - sowiecki działacz partyjny i państwowy; 1920-1924 przewodniczący Rady Komisarzy Ludowych BSRS, członek KC KP(b)B, po krytyce na XVI zjeździe KP(b)B popełnił samobójstwo; DM1, przyp. 88.

${ }^{35}$ Mikoła Wierszynin, Мікола Вершынін, profesor, zbieracz i archiwista, prezes Towarzystwa Białoruskiego w Pradze; inicjator założenia w 1928 (w oparciu o fundusze czechosłowackiego MSZ) Białoruskiego Archiwum Emigracyjnego w Pradze czeskiej.

36 Prawdopodobnie chodzi o Noaha Borowskiego (1885-1944) - tłumacza i redaktora m.in. prac w języku niemieckim (m.in. dzieł Lenina), pracownika wielu wydawnictw; w 1932 zatrudniony w wydawnictwie Izdatielstwo Innostrannych Raboczich, wówczas przełożył na j. niemiecki zarys historii Wszechzwiązkowej Komunistycznej Partii (bolszewików) N. Popowa (Moskwa 1932), pozwalając sobie w niemieckich komentarzach na delikatną krytykę i dystans do tłumaczonego tekstu. W konsekwencji został zwolniony; w 1938 aresztowany i osiedlony w Ałma Acie, gdzie zmarł; zob. http://www.yale.edu/annals/Chase/Documents/doc20chapt4.htm (dostęp: 1.01.2015).

37 Eduard Budźka (1882-1958) - publicysta; uczestnik I Zjazdu Wszechbiałoruskiego; w 1918 organizował Białoruskie Gimnazjum w Budsławiu, a w latach 1921-1940 kursy białorusoznawstwa na Litwie i Łotwie. W czasie okupacji niemieckiej (1941-1944) pracował jako nauczyciel w Mińsku i Baranowiczach; po wojnie wyemigrował do Niemiec, zmarł w USA; DM1, przyp. 71.

38 Bronisław Taraszkiewicz, Браніслаў Тарашкевіч, Branisłaŭ Taraškievič (1892-1938) - absolwent Uniwersytetu Petersburskiego (1916); wykładowca Katedry Języka Rosyjskiego i Słowianoznawstwa tamże (1916-1918); w BSH od 1917 jako jeden z jej liderów, od 1918 w Białoruskiej Partii Socjaldemokratycznej. Autorzy biogramów z reguły nie podają, iż po zamachu stanu 13.12.1919 wszedł do Rady Najwyższej, działającej do lata 1920 w oparciu o polskich zwolenników federacji. Jesienią 1920 wraz z Wacławem Iwanowskim wszedł do Tymczasowej Komisji Rządzącej Litwy Środkowej i w latach 1920-1922 był dyrektorem do spraw szkół białoruskich. Poseł na Sejm I kadencji i delegat Białoruskiego Komitetu Politycznego na rozmowy z Józefem Piłsudskim i premierem Antonim Ponikowskim; w 1925 założyciel Białoruskiej Włościańsko-Robotniczej Hromady, a następnie członek Komunistycznej Partii Zachodniej Białorusi (od grudnia 1925). W lutym 1930 skazany i wymieniony na osoby więzione w BSRS. W BSRS aresztowany (1937) i rozstrzelany; DM1, przyp. 49; http://pl.wikipedia.org/wiki/Bronis\%C5\%82aw_Taraszkiewicz (dostęp: 31.12.2014).

39 Sergiusz Baran, Siarhej Baran (1894-1937?) - członek Białoruskiej Partii Socjalistów-Rewolucjonistów, od 1919 prezes Białoruskiego Narodowego Komitetu w Grodnie i nauczyciel w tamtejszym Gimnazjum Białoruskim. W 1922 poseł Sejmu I kadencji. Aresztowany w 1923 i skazany w Białymstoku za organizację nielegalnej struktury powstańczej na Grodzieńszczyźnie. Zwolniony w 1927, w 1928 wyjechał z Polski. W 1930 rozpoczął studia w Wyższym Instytucie Pedagogicznym w Mińsku. Postaci tej poświęciła artykuł Helena Głogowska, zob.: H. Głogowska, Los białoruskiego posła Sergiusza Baranowa [sic], „Białoruskie Zeszyty Historyczne” 1995, z. 2, s. 146159; ACz, s. 28-32; DM1, przyp. 33.

40 Szymon Jakowiuk (1881-1973) - telegrafista na stacji Białystok (1900-1914), 1914-1918 w wojsku; we wrześniu 1918 pracownik Czeka; 1919 w kontakcie z Ministerstwem Spraw Białoruskich przy Rządzie Litwy; 1920 sekretarz Białoruskiego Komitetu Narodowego w Grodnie, sekretarz Zjazdu w Pradze; organizator antypolskiej partyzantki na Grodzieńszczyźnie; poseł na Sejm I kadencji; aresztowany w 1923, sądzony w toczącym się w Białymstoku procesie 45 Białorusinów. W grudniu 1923 uciekł do Kowna; ACz, s. 277-281; DM1, przyp. 38.

41 Salomon Łurje - zob. przyp. 29. 
Wydaje się, że strona polska, dysponując informacjami o umowie z 17 III 1923 r., położyła nacisk na monitorowanie działalności posłów białoruskich w Sejmie polskim, ponieważ z zapisów Umowy Mińskiej wynikało, że postanowiono wykorzystać ich obecność w Warszawie "jako, że nie wiadomo czy nam się jeszcze kiedy nawinie tak dogodna okazja”.

Białoruscy posłowie i senatorowie mieli:

- w ramach „przygotowywania gruntu” organizować kółka kulturalno-oświatowe, wiece, zjazdy i konferencje, na których informowaliby, zwłaszcza młodzież, o ruchu białoruskim.

- przy wykorzystaniu legalnych środków domagać się takich koncesji na rzecz Białorusinów jak otwieranie białoruskich szkół (zarówno średnich jak i specjalnych) druk gazet, broszur i książek zawierających „motywy szkodliwe dla Polski”.

- składać interpelacje w celu zwolnienia aresztowanych białoruskich działaczy oraz zabiegać o wejście w życie ustawy o amnestii, która automatycznie uwolni tych, których $\mathrm{z}$ więzienia nie uda się wydostać inną drogą.

Zabójstwo gen. Józefa Bałachowicza - brata gen. Stanisława Bułak-Bałachowicza - kojarzono w polskich kręgach wywiadowczych z postanowieniami WCIK (ВЦИК - Всероссийский Центральный Исполнительный Комитет), czyli Centralnego Komitetu Wykonawczego Republiki Sowieckiejw Mińsku z 1 lipca 1923 r., a mianowicie:

1) postanowieniem o wzmocnieniu i rozszerzeniu agitacji na całe terytorium Polski w celu wywołania przewrotu państwowego;

2) postanowieniem prowadzenia agitacji $\mathrm{w}$ ścisłym kontakcie $\mathrm{z}$ innymi ugrupowaniami białoruskimi. Zalecano m.in, by w miejscowościach, gdzie nastrój jest wybitnie religijny, wmawiać, że Polacy gnębią prawosławie;

3) zaleceniem stosowania terroru wobec ważniejszych urzędników administracyjnych;

4) zaleceniem wzmocnienia w Polsce kontrwywiadu wojskowego.

Dla realizacji tych celów WCIK postanowił wyasygnować środki w złocie ${ }^{42}$.

Sytuację oceniali jako poważną nie tylko przedstawiciele polskiej administracji państwowej, ale też sami Białorusini, którzy ofiarą swej krwi dowiedli swego białoruskiego patriotyzmu. W lipcu 1923 r. prezes Białoruskiego Komitetu Politycznego Wiaczesław Adamowicz ${ }^{43}$ zwrócił się do władz polskich z pismem, w którym

42 „Zarys ruchu białoruskiego”.

43 Wiaczesław Adamowicz, Вячаслаў Адамовіч (starszy) (1864-1939) - białoruski działacz narodowy; syn księdza prawosławnego, pułkownik carskiej armii, w latach 1907-1914 redaktor i wydawca gazety „Siewiero-Zapadnyj Telegraf” w Kownie; od 1917 członek Białoruskiej Socjalistycznej Hromady; uczestnik I Zjazdu Wszechbiałoruskiego w Mińsku; aktywny członek Centralnej Rady Wojskowej. W latach 1919-1920 zatrudniony w Białoruskiej Komisji Wojskowej; założyciel i przewodniczący Włościańskiej Partii Zielonego Dębu, politycznej reprezentacji oddziałów „zielonych” - partyzantki antysowieckiej złożonej z chłopów i dezerterów, której sztab rezydował w Łunińcu. 16 listopada 1920 w Mozyrzu ogłoszony premierem BRL (Stanisław Bułak-Bałachowicz został wówczas naczelnym wodzem). Na czele oddziałów zbrojnych Zielonego Dębu stał ataman Wiaczesław Adamowicz (młodszy), ps. Dziergacz. Organizacja współpracowała z polskim wywiadem wojskowym. Według Olega 
konstatował, że agitacja posłów Sejmu I kadencji: ks. Adama Stankiewicza ${ }^{44}$, Antoniego Owsianika $^{45}$, Szymona Rak-Michajłowskiego ${ }^{46}$, Piotra Miotły ${ }^{47}$, Wasyla Raguli $[\text { Rahuli }]^{48}$, senatora Aleksandra Własowa ${ }^{49}$ i Aleksego Nazarowskiego ${ }^{50}$, których

Łatyszonka, Włościańska Partia Zielonego Dębu została założona przez działaczy Białoruskiego Komitetu Politycznego w okresie przygotowań do ideowo-organizacyjnego zespolenia „zielonych” oddziałów, które przyłączyły się do sił Bułak-Bałachowicza; OŁ, s. 214; DM2, przyp. 314. Zob. też: Joanna Januszewska-Jurkiewicz, Raport atamana Tymoteusza Chwiedoszczeni dotyczący działalności partyzanckiej na terenie Białorusi sowieckiej w okresie 10-29 czerwca 1921 r., „Białoruskie Zeszyty Historyczne” 14 (2000); oraz prace Niny Stużyńskiej: N.I. Stużinska, Białoruski ruch antybolszewicki (1917-1925), w: Społeczeństwo białoruskie, litewskie i polskie na ziemiach pótnocno-wschodnich II Rzeczypospolitej w latach 1939-1941, red. M. Giżejewska, T. Strzembosz, Warszawa 1995, s. 360-364.

44 Adam Stankiewicz, Адам Станкевіч (1892-1949) - ksiądz, absolwent rzymskokatolickiego Seminarium Duchownego w Wilnie i Akademii Duchownej w Piotrogrodzie; w 1918 uzyskał doktorat z prawa kanonicznego; założyciel i przywódca Białoruskiej Chrześcijańskiej Demokracji. Po ustanowieniu Białoruskiej Republiki Ludowej członek Rady BRL. W 1919 przyjechał do Wilna. Redaktor i wydawca „Krynicy” (sierpień 1919 - wrzesień 1922); nauczyciel białoruskiego gimnazjum. W latach 1922-1928 poseł na Sejm z listy Bloku Mniejszości Narodowych, zastępca prezesa Białoruskiego Klubu Poselskiego; w latach 1924-1926 prezes Towarzystwa Szkoły Białoruskiej. Wraz z ks. Wincentym Godlewskim reprezentował chadecko-narodowy odłam w ruchu białoruskim, przeciwny opcji skierowanej ku Białoruskiej Socjalistycznej Republice Radzieckiej. Kierował Białoruskim Instytutem Gospodarki i Kultury. W 1944 aresztowany przez NKWD i skazany na 25 lat zesłania na Syberię, gdzie zmarł; EM, s. 296; ACz, s. 222-224; DM1, przyp. 39; http://pl.wikipedia.org/wiki/Adam_Stankiewicz (dostęp: 6.12.2014).

45 Antoni Owsianik, Антон Аўсянік, Anton Ausianik (1888-1933?) - absolwent Instytutu Technologicznego w Charkowie, student Wydziału Budowy Okrętów Politechniki Petersburskiej. W latach 1918-1919 przewodniczył Radzie Białoruskiej w Charkowie; lewicowy działacz państwowy Białoruskiej Republiki Ludowej (BRL), w latach 1918-1919 członek Rady BRL, Prezydium Rady BRL, Konwentu Seniorów Rady BRL, Ludowego Sekretariatu Białorusi; jeden z inicjatorów stworzenia białoruskich oddziałów wojskowych w składzie Wojska Polskiego, w latach 1919-1920 członek, a następnie wiceprzewodniczący tymczasowego prezydium Białoruskiej Komisji Wojskowej; w 1920 pełnomocny przedstawiciel BRL w Republice Litewskiej; przedstawiciel białoruskiej mniejszości narodowej w II Rzeczypospolitej, od 1922 poseł na Sejm I kadencji; w latach 30. wyjechał do Białoruskiej SRR, gdzie został aresztowany i prawdopodobnie zabity z polecenia władz radzieckich; DM1, przyp. 55; http://pl.wikipedia.org/wiki/Antoni_Owsianik (dostęp: 6.12.2014).

${ }^{46}$ Szymon Rak-Michajłowski (1885-1937) zob. przyp. 69.

47 Piotr Miotła (1890-1936) - w latach 1911-1912 na rosyjskich kursach pedagogicznych w Kownie; 1914-1917 na froncie; 1917-1921 nauczyciel. W 1922 poseł na Sejm I kadencji, organizator Białoruskiej Włościańsko-Robotniczej Hromady, aresztowany po jej delegalizacji (1927), skazany i wymieniony na więźniów politycznych z BSRS. W 1933 zesłany do łagru, gdzie zmarł; DM1, przyp. 59.

48 Wasyl Ragula zob. przyp. 64.

49 Aleksander Własow, Аляксандр Уласаў, Aleksandr Ułasau (1874-1941) - ziemianin (majątek Migówka), białoruski działacz polityczny i oświatowy; dziennikarz i wydawca; prezes Białoruskiego Narodowego Komitetu w Warszawie i Towarzystwa Szkoły Białoruskiej; senator parlamentu I kadencji. 16.10.1939 aresztowany przez NKWD; więziony w Wilejce i Mołodecznie; 29.11.1940 skazany na 5 lat łagru; zmarł 11.03.1941 w Nowosybirsku; ACz, s. 236-237; https://www.senat.edu.pl/ senat/senatorowie-1922-1939/senatorowie-ii-rp/senator/aleksander-wlasow (dostęp: 30.12.2014).

50 Aleksy Nazarewski (1881-po 1940) w latach 1902-1907 urzędnik Poczty i Telegrafu w Mińsku; w latach 1915-1918 organizator opieki nad uchodźcami w Moskwie; senator w parlamencie 
wręcz nazywał „agentami Mińska”, stworzyła groźną sytuację. Posłowie w swoich okręgach, według słów Wiaczesława Adamowicza, „siali bałamutną agitację wśród ciemnego ludu białoruskiego i usposabiali go wrogo względem Państwa Polskiego" ${ }^{51}$.

Zrozumiałe jest, iż w opisanej powyżej sytuacji zainteresowanie Departamentu Bezpieczeństwa w Warszawie wzbudziły przede wszystkim dwie osoby o znaczeniu znacznie większym od pozostałych: Anton Łuckiewicz i Józef Mamońko. Jesienią 1923 r. zwrócono się więc do Delegata Rządu w Wilnie z prośbą o wiadomości na ich temat. Odnalezioną informację o Antonie Luckiewiczu ${ }^{52} \mathrm{z}$ marca $1924 \mathrm{r}$. kończy wymowne zdanie: „Nie ma dwóch zdań, że Łuckiewicz jest w Wilnie najpokaźniejszym działaczem białoruskim.” Niestety, treść tego biogramu zdecydowanie odbiega swą zawartością od pozostałych i należy podkreślić, iż fakt ten skłania do stawiania pytań badawczych. Odnalezione informacje mają charakter wybitnie gawędziarski i wydaje się, że ich autor nie miał pojęcia, iż pisze o filarze Hromady $1903 \mathrm{r}$.

Podkreślono, iż krewni tego zaściankowego szlachcica $\mathrm{z}$ litewskiego powiatu szawelskiego nie uważali się za Białorusinów, a ich językiem domowym był

I kadencji (1922-1928); pracownik magistratu w Baranowiczach, aresztowany w 1940 przez NKWD; https://www.senat.edu.pl/senat/senatorowie-1922-1939/senatorowie-ii-rp/senator/aleksy-nazarewski (dostęp: 30.12.2014).

${ }^{51}$ AAN, zespół Policji Politycznej z Wilna, sygn. 7, k. 85-86, cytat z listu wysłanego w lipcu 1923 r. przez prezesa Białoruskiego Komitetu Politycznego, Z. Adamowicza, do władz polskich: „Czy przeciwstawia się tej robocie jakąkolwiek akcję? - zapytuje Adamowicz. - Z bólem serca stwierdzić trzeba - sam sobie odpowiada - że nic absolutnie: nawet nie ma gazety, która by rzucała właściwe światło na robotę tzw. Posłów Sejmu Warszawskiego, których raczej nazwać trzeba agentami Mińska [...] posłowie, korzystając z nietykalności osobistej, pracują jawnie przeciwko Polsce, propagując idee partii komunistycznej (poseł Stankiewicz na wiecu w Prozorokach w pow. dziśnieńskim ogłosił np., że w najbliższym czasie będzie ogłoszona autonomia Białorusi i Wschodnia Białoruś zostanie przyłączona do Zachodniej, a ziemia odebrana obszarnikowi) [...] Koniecznym jest zjednoczenie się wszystkich białoruskich grup, partii i organizacji stojących na gruncie orientacji polskiej i wspólne wystąpienie przeciwko orientacji bolszewickiej”; druk: „Zarys ruchu białoruskiego".

52 Anton Luckiewicz, Антон Іванавіч Луцкевіч (1884-1942?) - dorpatczyk (1902 ukończył Wydział Prawa),w 1903 był współzałożycielem Białoruskiej Rewolucyjnej Hromady; aktywny mason; inicjator Konfederacji Wielkiego Księstwa Litewskiego, członek rządu BRL od marca 1918, premier BRL od października 1918, po zamachu 13.12.1919 r. nadal premier BRL, od lutego 1920 Rady Najwyższej. Jako premier BRL podpisywał się jeszcze w lipcu $1920 \mathrm{r}$. W roku 1921 formalnie jedynie przewodniczący Białoruskiego Komitetu Narodowego w Wilnie. Kierował Muzeum Białoruskim im. Iwana Łuckiewicza w Wilnie. Aresztowany w 1927 r. pod zarzutem współpracy z białoruską socjaldemokracją. Po wyjściu z aresztu pracował w Gimnazjum Białoruskim w Wilnie (zwolniony w 1931). W latach 1933-1939 zakazano druku jego publicystyki na terenie RP. We wrześniu 1939 aresztowany przez NKWD. Przesłuchiwany. Okoliczności śmierci nieznane; EM, s. 292; ACz, s. 156-158; DM1, przyp. 15; zob. też: http://pl.wikipedia.org/ wiki/Anton_\%C5\%81uckiewicz (dostęp: 6.12.2014). 
język polski ${ }^{53}$. Sam Łuckiewicz, zarówno w trakcie studiów w Petersburgu jak i w Dorpacie, miał się uważać za Polaka. Wbrew powszechnie znanym faktom, pierwszym odnotowanym przez agentów Służby Informacyjnej objawem aktywności politycznej Łuckiewicza miał być jego udział w utworzeniu Kowieńsko-Wileńskiego Komitetu Obywatelskiego w celu zwalczania Niemców, a pomysł ten zniweczyć miały spory polsko-litewskie. Następnym etapem działalności Łuckiewicza miała być jego aktywność w Konfederacji Wielkiego Księstwa Litewskiego, a trzecim - praca na niwie oświaty oraz w Białoruskim Towarzystwie Pomocy Ofiarom Wojny.

Według odnalezionej charakterystyki Łuckiewicza, jego konsekwentna linia polityczna, zmierzająca do budowy państwa litewsko-białoruskiego, weszła w kolizję z polityką niemiecką ${ }^{54}$. Według wiedzy funkcjonariusza Oddziału Informacyjnego w 1924 r. odbudowa państwa litewsko-białoruskiego absolutnie nie leżała w niemieckich planach, a Niemcy początkowo zamierzali stworzyć Małą Litwę z ziem etnicznie litewskich oraz z Wileńszczyzny i Grodzieńszczyzny. Dopiero zmiana sytuacji na froncie i rewolucja w Niemczech zmusiły ich w roku 1918 do okrojenia pierwotnych planów. Łuckiewicz wraz bratem Janem mieli ostro występować przeciw niemieckim okupantom jeszcze w trakcie mityngu socjalistycznego w Wilnie, który miał miejsce w roku 1917. Reakcją Łuckiewicza na Zjazd Litewski było jakoby doprowadzenie do Zjazdu Białoruskiego w Wilnie, na którym (25 lutego 1918 r.) powołano wileńską Białoruską Radę.

Autor opracowania sugerował też istnienie porozumienia niemiecko-bolszewickiego, w wyniku którego doszło do swego rodzaju pacyfikacji Rady Białoruskiej Republiki Narodowej (inaczej Białoruskiej Republiki Ludowej) ${ }^{55}$ przebywającej w tym czasie w Mińsku. Dał również wyraz swemu przekonaniu, iż to brak sukcesów Rady w Mińsku i zmiana sytuacji militarno-politycznej w Europie ostatecznie miały skłonić Białorusinów do skierowania swych państwowotwórczych nadziei w stronę państwowości litewskiej. Politycy Białoruskiej Republiki Ludowej bez zawierania międzypaństwowej umowy - co istotne - po prostu przyjęli sześć miejsc w Tarybie ${ }^{56}$ oraz tekę Ministra Spraw Białoruskich.

53 Obaj bracia Łuckiewiczowie - Anton i Jan - prowadzili piękną polszczyzną korespondencję $\mathrm{z}$ własną matką. Fragmenty tej korespondencji znajdują się w tzw. dopływie Muzeum Białoruskiego (2012) w LCVA w Wilnie.

${ }^{54}$ Por. J. Gierowska-Kałłaur, Kwestia dostępu odradzającego się państwa polskiego do Morza Battyckiego a interesy Niemiec, w: Między historia polityczna a historia społeczną. Księga jubileuszowa ofiarowana profesorowi Andrzejowi Skrzypkowi w siedemdziesięciolecie urodzin, red. J. Gołota, Pułtusk-Olsztyn-Ostrołęka-Warszawa 2014, s. 64-81.

55 Zob. D. Michaluk, Białoruska Republika Ludowa 1918-1920. U podstaw białoruskiej państwowości, Toruń 2010.

56 Według pozyskanych przez Agenturę Informacyjną wiadomości ówczesna Taryba oprócz spotkań, w których brali udział Białorusini i Żydzi, w ważniejszych sprawach odbywała narady bez udziału tzw. inorodców. Taki stan rzeczy miał spowodować demonstracyjne wystąpienie Białorusinów z Taryby. 
Okres 1919-1920 potraktowany jest w biogramie Łuckiewicza wręcz zaskakująco nieprofesjonalnie. Nie ma w nim nawet słowa o okolicznościach brzemiennego dla Białorusi zamachu stanu 13 grudnia 1919 r. i o rozpoczęciu - z formalnego punktu widzenia - etapu białoruskiej dwuwładzy ${ }^{57}$.

Szeroko natomiast opisano okoliczności rewizji przeprowadzonej 1 listopada 1920 r. w mieszkaniu Antona Łuckiewicza na rozkaz Oddziału II Dowództwa Wojskowego Litwy Środkowej. Skonfiskowano wówczas rękopisy oraz broszurę Polska okupacja Białorusi, dostępną w księgarniach do 1 listopada 1920 r. i - według jego słów - napisaną przez niego jeszcze przed utworzeniem Litwy Środkowej.

Ten fakt zmusza do postawienia nowych pytań badawczych dotyczących Antona Łuckiewicza, który - według informacji Oddziału II - do lipca 1920 r. otrzymywał (za pośrednictwem Rady Najwyższej) wsparcie Belwederu, którym zresztą dzielić się miał z politykami BRL w Kownie.

W zamian za obietnicę pozostania w Wilnie Łuckiewiczowi dano ponoć swobodę działania, co pozwoliło mu brać udział we wszystkich białoruskich instytucjach, prowadzić politykę zagraniczną, organizować - jak to określono w biogramie - struktury „tajnej białoruskiej agentury” i sprawować „nadzór nad wszystkimi działaczami w Wilnie". Według odnalezionych informacji był on głównym animatorem bojkotu wyborów do Sejmu Wileńskiego i świadomie odmówił wystawienia swojej kandydatury w wyborach do Sejmu Warszawskiego. Pozostając konsekwentnie w cieniu, nie miał związanych rąk i pisał ostre artykuły nie, ponosząc za nie żadnych konsekwencji, gdyż tę brali na siebie redaktorzy gazet Józef Łohinowicz (o którym za chwilę) i Mikołaj Szyło.

Wydaje się zrozumiałe, że obiektem zainteresowania polskich służb bezpieczeństwa stał się również Józef Mamońko ${ }^{58}$. Ten białoruski polityk, w 1923 r.

57 O wydarzeniach tych tak pisze autor „Zarysu ruchu białoruskiego”: „W miesiąc potem dn. 12 XII 1919 ponownie zebrała się Rada Republiki. Nie mogąc dojść do żadnego porozumienia w plenum, ugodowa część Rady zaproponowała utworzyć coś w rodzaju dyrektoriatu względnie Rady Najwyższej, złożonej tylko z kilku osób. Eserzy będący w mniejszości projekt ten potępili kategorycznie i Rada rozeszła się. Na drugi dzień - 13 XII [1919] - eserzy i ich sympatycy (socjalfederaliści) zebrali się w liczbie 50 osób w lokalu Rady i nie dopuszczając na salę swych przeciwników ogłosili się pełną Radą, wykluczając z niej mniejszość ugodową - 37 osób. Rada ta [w nowym składzie] wniosła rezolucję protestującą przeciwko „polskiej okupacji” Białorusi, potwierdziła akt o niezależności Białoruskiej Republiki i wybrała nowe Prezydium. Prezesem Rady Republiki został Kreczewski, zaś prezesem ministrów Wacław Łastowski” (s. 53). D. Michaluk (Białoruska Republika Ludowa 1918-1920. U podstaw białoruskiej państwowości, Toruń 2010, inaczej przedstawia przebieg tamtych wydarzeń.

58 Józef Mamońko, Иосиф Алексеевич Мамонько (1889-1937) - działacz polityczny, w 1907-1917 członek partii rosyjskich eserów, a w latach 1918-1924 - Białoruskiej Partii Socjalistów-Rewolucjonistów. Od roku 1919 w Prezydium BRL. W 1920 aresztowany i wysłany do Kowna. W 1921 i 1925 r. uczestniczył w konferencji praskiej. Aresztowany w Mińsku w 1928 i rozstrzelany na zesłaniu w 1937; DM1, przyp. 93; https://www.google.pl/?gws_rd=ssl\#q=j\%C3\%B3zef+mamo\%C5\%84ko (dostęp: 6.12.2014). 
przebywający w czeskiej Pradze, w listopadzie 1919 r. w Smoleńsku wraz z Pałutą Badunową podpisał w imieniu BPSR umowę z bolszewikami. W konsekwencji wystąpił 13 grudnia 1919 r. przeciwko polityce premiera Antona Łuckiewicza deklarującej budowę państwa w porozumieniu z Polską. Mamońko - według odnalezionej informacji - był współorganizatorem przewrotu w Radzie BRL przeciw Łuckiewiczowi i w konsekwencji doprowadził do utworzenia Rady w nowym składzie, zdecydowanie opozycyjnym wobec dotychczasowej linii politycznej Rady BRL - tę linię polityczną natomiast kontynuowała Rada Najwyższa.

Ustalenia dotyczące Józefa Mamońki poczynione w okresie Litwy Środkowej zostały wykorzystane w opinii sporządzanej w grudniu 1923 r. na specjalną prośbę Ministerstwa Spraw Wewnętrznych. Warto zwrócić uwagę na fakt, iż odbiegają swą szczegółowością i dokładnością od informacji podawanych dotychczas w przypisach biograficznych.

Mamońko był synem włościanina z powiatu słuckiego, a wykształcenie otrzymał w szkole miejskiej. Z zawodu był telegrafistą. W 1903 r. został powołany do inżynieryjnej kompanii fortecznej w Kownie. Tam wstąpił do silnej organizacji socjalrewolucjonistów. Według informacji Policji Politycznej kowieńska organizacja socjalrewolucjonistów była punktem przerzutowym dla rosyjskich SR uciekających za granicę. Również przez Kowno zaopatrywali się oni w broń, bomby i literaturę. Młody Mamońko miał już wówczas należeć do frakcji terrorystycznej tej partii. Cieszył się uznaniem liderów, jako że ,jego rewolucyjne usposobienie poparte było zdecydowanym charakterem, osobistą odwagą, wrodzonym sprytem i bystrą orientacją. Powierzano mu sprawy ryzykowne i nigdy nie zawiódł pokładanego w nim zaufania”.

Koniec służby wojskowej Mamońki zbiegł się z końcem rewolucji. W $1906 \mathrm{r}$. Mamońko wrócił na ziemię słucką, gdzie w przeciągu kilku lat, chodząc od wioski do wioski, stworzył lokalną organizację socjalrewolucjonistów, która istniała aż do czasu wojny światowej. Brak jakichkolwiek informacji o „syberyjskim epizodzie” w jego życiu potwierdza zasadność wątpliwości Olega Łatyszonka co do rzekomej zsyłki Mamońki na Syberię.

W chwili wybuchu wojny Mamońko ponownie został powołany do służby wojskowej w wojskach inżynieryjnych i - według informacji Policji Politycznej - ponownie zaangażował się we współpracę z elementami skrajnie lewicowymi.

Wybuch rewolucji lutowej zastał go na froncie północno-zachodnim, gdzie dość silną agitację prowadziła w tym czasie „Białoruska Grupa Socjalistyczna”. Mamońko zaangażował się w jej działalność, wziął udział w Kongresie partyjnym w Mińsku i uczestniczył w opracowaniu nowego statutu partii i planu działalności.

W okresie kiereńszczyzny Mamońko działał na froncie północno-zachodnim, gdzie zgodnie z dyrektywami Centralnego Komitetu Białoruskiej Grupy Socjalistycznej dążył do utworzenia Korpusu Białoruskiego.

Centralny Komitet Białoruskiej Grupy Socjalistycznej zwołał w Mińsku konferencję przedstawicieli wszystkich Białoruskich Rad Wojskowych ze wszystkich frontów i w trakcie posiedzenia (które odbyło się w zagarniętym rewolucyjnym 
poriadkom dawnym domu gubernatora) utworzona została, według danych Policji Politycznej, 30-osobowa Centralna Białoruska Rada Wojskowa (CBRW), której przewodniczącym został Szymon Rak-Michajłowski, a wiceprzewodniczącymi Wiaczesław Adamowicz i Jaroszewicz. Jednym z członków CBRW został delegat Rady Frontu Północno-Zachodniego, Józef Mamońko.

Wobec przeszkód, jakie stawiała władza bolszewicka w trakcie formowania 1-go Mińskiego Białoruskiego Pułku Strzelców, na komisarza tego pułku wyznaczono Mamońkę, który prowadził rozmowy z mińskim komisarzem ds. wojskowych - Miasnikowem ${ }^{59}$. Ponieważ negocjacje z bolszewikami nie były zadowalające, Wielka Rada Białoruska miała postanowić zwołanie w Mińsku - wbrew zakazowi bolszewików - Zjazdu Wszechbiałoruskiego. Istotną konsekwencją zjazdu był rozpad Białoruskiej Grupy Socjalistycznej, jako że jedni przyłączyli się do bolszewików, inni do licznie reprezentowanych na zjeździe eserów rosyjskich, a jeszcze inni uznali się za bezpartyjnych. Mamońko przystał do przybyłych z Petersburga i Moskwy „białoruskich SR” i wraz z Pałutą Badunową ${ }^{60}$ i Tomaszem Grybem ${ }^{61}$ utworzył „Białoruską Partię SR”.

59 Aleksandr Fiodorowicz Miasnikian znany także jako Miasnikow, Александр Фёдорович Мясников, Аляксандр Фёдаравіч Мяснікоў (1886-1925) - radziecki komunista ormiańskiego pochodzenia. Od września 1917 do maja 1918 stał na czele Północno-Zachodniego Komitetu RKP(b). Od listopada 1917 odpowiedzialny za dowodzenie na froncie zachodnim, rozpędzał m.in. I Kongres Wszechbiałoruski w Mińsku. Od 1919 członek KC KP(b)B, w latach 1919-1920 członek KC Komunistycznej Partii Litwy i Białorusi. Od stycznia do lutego 1919 członek Tymczasowego Rządu Białoruskiej SRR, zasiadał w Komitecie Centralnym KP(b)B. W lutym 1919 premier Białoruskiej SRR (przewodniczący Centralnego Komitetu Wykonawczego Białoruskiej Socjalistycznej Republiki Radzieckiej, zastępca przewodniczącego Rady Komisarzy Ludowych i komisarz spraw wojskowych). Kontuzjowany w zamachu w Moskwie (IX 1919). Następnie premier Armeńskiej SRR, prezydent Zakaukaskiej Federacyjnej Socjalistycznej Republiki Radzieckiej (w składzie Gruzji, Azerbejdżanu i Armenii), pierwszy sekretarz partii bolszewickiej Zakaukaskiej FSRR, członek Rewolucyjnej Rady Wojskowej ZSRR (kolegialnego kierownictwa Armii Czerwonej), członek Prezydium Centralnego Komitetu Wykonawczego ZSRR; DM1, przyp. 26; http://pl.wikipedia.org/wiki/Aleksandr_Miasnikian (dostęp: 6.12.2014).

${ }^{60}$ Pałuta Badunowa, Палута (Пелагея) Аляксандраўна Бадунова (1885-1938) - nauczycielka języka rosyjskiego z Homelszczyzny. W czasie I wojny światowej w Piotrogrodzie nawiązała kontakty ze środowiskami lewicowymi. W czerwcu 1917 weszła w skład KC BSH. Jako przedstawicielka Hromady była deputowaną do Piotrogrodzkiej Rady Delegatów Robotniczych i Chłopskich. Po rozłamie przyłączyła się do białoruskich eserów i została sekretarzem KC partii. Uczestniczyła w I Wszechbiałoruskim Zjeździe w Mińsku. Była liderką białoruskich socjal-rewolucjonistów, od lutego 1918 w rządzie i Radzie BRL (pełniła funkcję sekretarza opieki społecznej). Przyczyniła się do powstania licznych szkół i przytułków na terenie BSR, współzakładała dobroczynne towarzystwo „Ciotka” w Mińsku. 12 listopada 1919 wybrana na wiceprzewodniczącą Rady BRL. Aresztowana w wyniku zamachu stanu z 13 grudnia 1919. W kwietniu 1920 była członkiem delegacji BPSR $\mathrm{w}$ rozmowach $\mathrm{z}$ rosyjskimi bolszewikami na temat współpracy politycznej, liczyła na przekształcenie Białoruskiej Socjalistycznej Republiki Radzieckiej w narodowe państwo białoruskie. Aresztowana przez bolszewików i zwolniona ze względu na stan zdrowia. Nielegalnie przekroczyła granicę białorusko-polską i zamieszkała w Wilnie (grudzień 1922), została jednak wydalona $\mathrm{z}$ terytorium RP. Podjęła studia w Wyższym Pedagogicznym Instytucie 
Według danych Wikipedii, bardzo skrupulatnie uzupełnianych przez liczne grono białoruskich wolontariuszy, Mamońko jeszcze pod koniec 1919 r. wraz z innymi eserami (Pałutą Badunową, Tomaszem Hrybem, Trachimowem) założył Białoruski Komitet Powstańczy (BKP), którego zadaniem było zorganizowanie na Białorusi antypolskiego powstania. Wskutek dekonspiracji Mamońki został wydalony przez polskie władze do Kowna. Na początku 1921 r., na polecenie Wacława Łastowskiego, Aleksandra Ćwikiewicza i Alaksandra Haławinskiego [Gołowińskiego] przyjechał do Mińska w celu koordynacji podziemnej „walki rewolucyjnej” przeciwko władzy polskiej na ziemiach północno-wschodnich II Rzeczypospolitej ${ }^{62}$.

Warto tu bardzo wyraźnie zaznaczyć, że autor opracowania Policji Politycznej z połowy 1924 r. źródeł konfliktu pomiędzy BPSR a bolszewikami w trakcie I Zjazdu Wszechbiałoruskiego upatrywał nie $\mathrm{w}$ różnicach programowych, lecz $\mathrm{w}$ chęci zdobycia władzy.

Ukraińskim im. M. Drahomanowa w Pradze (1923-1925). Po rozwiązaniu BPSR na zjeździe w Mińsku w październiku 1924, w styczniu 1925, zachęcona efektami polityki białorutenizacji, wróciła do BSRR, podjęła współpracę z Inbiełkultem w Mińsku. W 1930 wyjechała na Homelszczyznę, gdzie pracowała jako nauczycielka. Aresztowana i skazana na 10 lat łagru. Ostatecznie rozstrzelana 29 listopada 1938 w Mińsku; Лебедзева В., Пуиявінамі змагання і пакутаў: Палута Бадунова, Mińsk 2004; http://pl.wikipedia.org/wiki/Pa\%C5\%82uta_Badunowa (dostęp: 30.12.2014).

61 Tomasz Hryb, Тамаш Грыб (1895-1938) - białoruski działacz polityczny i publicysta; wszedł w skład Centralnego Komitetu Wykonawczego I Wszechrosyjskiego Zjazdu Rad. W lipcu 1917 r. wstąpił do Białoruskiej Robotniczej Hromady, wchodząc później w skład Komitetu Centralnego. Równolegle został też członkiem Rosyjskiej Partii Komunistycznej (bolszewików) i uczestniczył w rewolucji październikowej. Wystąpił z RKP(b). Uczestniczył w wojskowych zjazdach Białorusinów w Piotrogrodzie i Witebsku, gdzie wybrano go w skład Centralnej Białoruskiej Rady Wojskowej. W grudniu 1917 uczestniczył w obradach I Kongresu Wszechbiałoruskiego w Mińsku jako członek prezydium. W styczniu 1918 brał udział w III Wszechrosyjskim Zjeździe Rad jako delegat wojskowych-Białorusinów. Wystąpił z protestem przeciwko rozgonieniu Kongresu Wszechbiałoruskiego przez bolszewików i podziałowi Białorusi na mocy Traktatu Brzeskiego. W marcu tego roku został członkiem Rady BRL. Był współautorem konstytucyjnych hramot BRL. Po zajęciu ziem białoruskich przez wojska niemieckie objął funkcję sekretarza w szkolnej sekcji urzędu miejskiego Mińska. Pod jego kierownictwem powstał Białoruski Związek Nauczycielski. Od stycznia do kwietnia 1919 r., w czasie okupacji bolszewickiej w Wilnie pracował jako nauczyciel. Założył i przewodniczył Białoruskiej Partii Socjalistów-Rewolucjonistów. Aresztowany przez władze ZCZW. Po zwolnieniu znalazł się w Kownie (1920) a od 1922 w Pradze. W latach 1934-1938 był kierownikiem Białoruskiego Archiwum Zagranicznego w Pradze; ACz, s. 69-70; http://pl.wikipedia.org/wiki/Tamasz_Hryb (dostęp: 6.12.2014); zob. M. Kietliński, W. Śleszyński, Repatriacje i migracje ludności pogranicza $w$ XX wieku. Stan badań oraz źródła do dziejów pogranicza polsko-litewsko-białoruskiego, Białystok 2004, s. 27; DM1, przyp. 92.

${ }_{62}$ W marcu 1921 r. J. Mamońko został aresztowany w Mińsku przez władze sowieckie i przewieziony do Moskwy. Z Kazania, dokąd - wg Wikipedii - go zesłano, zdołał uciec do Kowna. Dzięki temu we wrześniu 1921 r. wziął udział w Pierwszej Wszechbiałoruskiej Konferencji Politycznej w Pradze, gdzie ostro krytykował radzieckie władze Białorusi. Od końca 1922 r. mieszkał na stałe w Czechosłowacji. W październiku 1923 r. razem z Badunową protestował przeciwko utworzeniu w Kownie rządu BRL na czele z Ćwikiewiczem i uznał go za nielegalny; DM1, przyp. 93; http://pl.wikipedia.org/wiki/Jazep_Mamo\%C5\%84ka (dostęp: 6.12.2014). 
Wśród działaczy, których charakterystyki odnalazłam, jest kilku posłów do polskiego Sejmu. Nie jest jednak przedmiotem mojego zainteresowania ich działalność parlamentarna ${ }^{63}$. Odnalezione opinie dotyczą czterech posłów parlamentu I kadencji: Bazylego Rahuli, Fabiana Jeremicza, Szymona Rak-Michajłowskiego i Michała Kochanowicza.

Bazyli Rahula (Wasyl Ragula) pozostawił po sobie wspomnienia dzięki czemu jego życiorys jest dość dobrze znany ${ }^{64}$. Pozostaje jedynie zadać pytanie - na ile poznajemy obraz rzeczywisty, a na ile - wykreowany przez autora?

Syn chłopa, absolwent rosyjskiego seminarium nauczycielskiego i Wileńskiego Instytutu Nauczycielskiego w 1905 r. za agitację w Ziemi Wileńskiej - „wg jego własnych słów" - miał zostać skazany. Z nieznanych przyczyn został jednak zwolniony i natychmiast przyjęty na posadę nauczyciela szkoły ludowej w Mińsku, co w opinii autora informacji z 1924 r. było równoznaczne z tym, że Rahula po prostu nie mógł być uważany przez ówczesne władze za człowieka politycznie nieprawomyślnego.

Powołany w 1914 r. do armii rosyjskiej miał służyć w Orszy i Smoleńsku gdzie - jak podaje cytowane źródło - pozostawał przez kilka lat na stanowisku „zhurad wojennawo czynownika”. Brał udział w prowadzonej w 1917 r. agitacji przeciw wojnie i oficerom. Aktywnie uczestniczył w pierwszych wystąpieniach bolszewickich i „wraz z rozbestwionym tłumem żołnierzy zrywał epolety oficerom

${ }^{63}$ O działalności posłów białoruskich w tym okresie zob. A. Paszkiewicz, Białoruska reprezentacja w parlamencie II Rzeczypospolitej pierwszej kadencji (1922-1927), „Przegląd Wschodni” 9 (2004), z. 3 (35), s. 551-574.

${ }^{64}$ Bazyli Rahula, Wasyl Ragula, Васіль Рагуля (1879-1955) - w 1898 ukończył szkołę średnią w Mołodecznie, w 1906 Instytut Pedagogiczny w Wilnie; nauczyciel w Smorgoniach i Mińsku; w 1906 aresztowany przez władze carskie za udział w ruchu rewolucyjnym. W czasie I wojny światowej walczył na froncie zachodnim; w 1917 wstąpił do Rosyjskiej Partii Demokratycznej. Na zjeździe nauczycieli guberni mińskiej w maju 1917 przeciwstawiał się wprowadzeniu do szkół nauczania w j. białoruskim; w tym samym roku uczestnik I Kongresu Wszechbiałoruskiego w Mińsku (orientacja prorosyjska). W 1918 ponownie uczył w Mińsku. 1919-1920 członek antypolskiej Rosyjskiej Zjednoczonej Grupy Radykalno-Demokratycznej. Zmobilizowany latem 1920 do Armii Czerwonej, w 1921 opuścił jej szeregi i powrócił w rodzinne strony. Od 1922 był posłem do polskiego sejmu w składzie Białoruskiego Klubu Poselskiego. W listopadzie 1925 utworzył wraz z Fabianem Jeremiczem, Wsiewaładem Bildziukiewiczem i Bronisławem Turonkiem nową partię polityczną: Białoruski Związek Włościański. W grudniu 1925 był jednym z inicjatorów utworzenia Białoruskiego Instytutu Gospodarki i Kultury. W 1928 senator, wkrótce pozbawiony immunitetu i aresztowany; skazany na karę 2 lat więzienia. Po wyjściu na wolność wrócił w rodzinne strony, do wsi Aczukiewicze/Ociukiewicze (pow. Nowogródek), gdzie mieszkał do wybuchu wojny. W 1939, po zajęciu zachodniej części Białorusi przez Armię Czerwoną, pracował w szkole w Lubczy. 20 czerwca 1941 aresztowany przez NKWD, ale w chwili wybuchu wojny radziecko-niemieckiej udało mu się zbiec z transportu. W czasie niemieckiej okupacji podjął współpracę z Niemcami. Prezes Białoruskiego Komitetu Gminnego, a następnie burmistrz Dziatłowa (wg in. źródeł Zdzięcioła). W 1944 wiceprezes białoruskiego kongresu zwołanego w Mińsku przez Białoruską Centralną Radę (przy poparciu niemieckich władz okupacyjnych); 3 lipca 1944 razem $\mathrm{z}$ cofającym się frontem niemieckim dotarł w głąb Niemiec; w 1950 wyjechał do USA; zob. W. Ragula, Wspaminy, NY 1957; ACz, s. 194-195; DM1, przyp. 14; https://www.senat. edu.pl/senat/senatorowie-1922-1939/senatorowie-ii-rp/senator/bazyli-rogula (dostęp: 6.12.2014). 
a nawet, podobno, brał udział w znęcaniu się nad niektórymi oficerami i w rabowaniu składów wojskowych". Dane te zbieżne są z ustaleniami, znajdującymi się na stronach polskiego Sejmu.

Według autora omawianej opinii o Rahuli w 1917 r. ruch narodowościowy białoruski był na tyle silny, że zaniepokoił bolszewików, którzy postanowili go spacyfikować. Rahula sam miał zaproponować głównodowodzącemu w Mińsku Miasnikowowi swe usługi i „chętnie wziął na siebie, oczywiście nie za darmo, rolę bolszewickiego szpiega i prowokatora”. Ponieważ wszedł do Centralnej Rady Wojskowej i Wielkiej Rady Białoruskiej, „wszystko co czyniły, zawdzięczając Raguli, było wiadomem Miasnikowowi".

Rola Rahuli w trakcie Zjazdu Wszechbiałoruskiego miała być co najmniej nieciekawa. Rahula otrzymał od Miasnikowa polecenie doprowadzenia do „zawarcia umów". Ponieważ pomimo usilnych zabiegów Rahuli zjazd propozycji tych nie przyjmował, to właśnie on miał wywołać powszechnie znany rozwój wypadków, powiadamiając Miasnikowa o „niekorzystnym” obrocie sprawy. Zjazd, jak wiadomo, został rozpędzony. Panowała opinia (ponoć znana bardzo dobrze białoruskim eserom), iż osobistą zasługą Rahuli było również rozpędzenie przez bolszewików innego zjazdu, w Smoleńsku, gdzie aresztowano przeszło stu Białorusinów i kilku z nich rozstrzelano. Jak czytamy w odnalezionej opinii, pomimo świadomości, kim w rzeczywistości jest Rahula, żaden z Białorusinów nie protestował przeciw jego kandydaturze do sejmu warszawskiego w $1921 \mathrm{r}$.

Autor opinii interpretowal to jako efekt istnienia umowy o jednolitym froncie socjalrewolucjonistów i bolszewików przeciwko Polsce. Rahula został w raporcie uznany nie za białoruskiego patriotę, lecz za agenta Białoruskiej Partii Komunistycznej „a może i GPU”.

Kolejny poseł na Sejm I kadencji, Fabian Jeremicz ${ }^{65}$ (który w odnalezionym tekście występuje jako Jeremicz) (ur. 1891) był również synem chłopskim. Ukończył szkołę ludową, kursy telegraficzne, szkołę elektrotechniczną w Petersburgu (1912). W trakcie nauki w tej ostatniej został członkiem partii socjaldemokratów. Bardzo charakterystyczny jest sporządzony w 1924 r. opis drogi życiowej Jeremicza:

Nie obdarzony żadnymi zdolnościami i od dzieciństwa nie widząc nic innego prócz zabobonów i nędzy, młody Jeremicz nie potrafił oczywiście, odnieść się krytycznie do tanich

65 Jeremicz (Jaremicz) Fabian, Фабіян Ярэміч (1891-1958), absolwent szkoły elektrotechnicznej w Petersburgu (1912), od 1917 białoruski działacz polityczny i społeczny, od 1918 w Białoruskiej Partii Socjalistów-Rewolucjonistów, potem w Partii Socjaldemokratycznej, od 1919 w Centralnej Radzie Wileńszczyzny i Grodzieńszczyzny. Poseł na Sejm II RP, od 1926 przewodniczący Białoruskiego Związku Chłopskiego. W czasie okupacji niemieckiej - burmistrz Borysławia. Po wojnie aresztowany przez NKWD lata do 1956 spędził w łagrach. Po uwolnieniu osiadł w Wilnie; EM, s. 289; ACz, s. 289-290; DM1, przyp. 46; http://pl.wikipedia.org/wiki/Fabian_Jeremicz (dostęp: 6.12.2014); http://bs.sejm.gov.pl/F?func=findb\&request=000002125\&find_code=SYS\&local_base=ARS10 (dostęp: 6.12.2014). 
krzykaczy ulicznych. Pociągały go idee rewolucyjne, zaś samą rewolucję wyobrażał sobie w najbardziej tęczowych kolorach. Prostemu wiejskiemu chłopcu o ciasnym światopoglądzie, który trafił w stolicy do nieznanego sobie otoczenia, dalekiego od wiejskiego ubóstwa, zechciało mu się odegrać rolę rewolucjonisty, chociaż nie mógł on dobrze zrozumieć ani programu s-d partii, ani tego szlaku, którym kroczyli rewolucjoniści rosyjscy. Niepojmowanie idei rewolucji, ograniczenie umysłowe, zupełny brak stanowczych zasad, moralne kalectwo duszy - wszystko to się przyczyniło do tego, że Fabian Jeremicz po powrocie z Petersburga do Wilna i po wstąpieniu na służbę w urzędzie pocztowo-telegraficznym, gdzie w tym czasie panowały silne prądy czarnosecinne, od razu przestał być członkiem S-D ${ }^{66}$ wstępując natomiast do znanego stowarzyszenia czarnej sotni tzw. „związku Michała Archanioła”, założonego przez Furyszkiewicza. [W „Związku Michała Archanioła” Jeremicz był chorążym i było w Wilnie bardzo wielu świadków jego aktywnego udziału w latach 1911-1913 w „czarnosecinnych manifestacjach”.] Jeremicz zbliżył się bardzo z Sołoniewiczem, pseudo-Białorusinem, redaktorem gazet białoruskich w języku rosyjskim, na które otrzymywane były od rządu carskiego dość znaczne subsydia pieniężne. Wg posiadanych informacji, Jeremicz w tym czasie zaczął uważać się za Białorusina i uczęszczać do „Wileńskiego Ogólnego Towarzystwa Białoruskiego”, założonego przez Sołoniewicza.

W 1917 r. Jeremicz miał zerwać kontakty z czarną sotnią i opowiedzieć się po stronie rewolucji. Podczas zajęcia Wilna przez bolszewików służył na stacji towarowej Wilno, gdzie kierował tzw. prowianturą. Podejrzewano go o kradzież znacznej ilości cukru w trakcie ewakuacji bolszewików i perfidne fizyczne pozbycie się rękoma przypadkowych polskich ułanów jedynego świadka tej kradzieży - wagowego. Ułani, wezwani przez Jeremicza na pomoc przeciw rzekomemu napastnikowi, usiekli nieszczęśnika na miejscu.

W okresie istnienia Zarządu Cywilnego Ziem Wschodnich (1919-1920) Jeremicz znalazł się w składzie Wileńskiego Narodowego Komitetu Białoruskiego, ponownie jako przedstawiciel S-D, tym razem socjaldemokracji pracowników kolejowych. Swoją nominację na prezesa [sic! tak w źródle] Klubu Białoruskiego Wileńskiego Komitetu Narodowego ${ }^{67}$ - paradoksalnie - miał zawdzięczać swej powszechnie znanej skłonności do ulegania wpływom, którą postanowił wykorzystać Anton Łuckiewicz. Charakterystyczny jest brak w notatce informacji o niewątpliwej działalności Jeremicza w Oddziałach Białoruskich. Dalsze jego losy potwierdzają opinię z 1924 r. o braku jasno wytyczonej drogi życiowej tego człowieka ${ }^{68}$.

66 Tzn. partii socjaldemokratycznej.

67 Poseł na Sejm RP I, II i III kadencji (1922-1935), reprezentował okręgi Pińsk i Nowogródek. W latach 1922-1925 pełnił funkcję wiceszefa Klubu Białoruskiego w parlamencie; http://bs.sejm. gov.pl/F?func=findb\&request=000002125\&find_code=SYS\&local_base=ARS10 (dostęp: 6.12.2014).

${ }^{68} \mathrm{~W}$ latach 30. był osadnikiem wojskowym na tzw. Kresach Północno-Wschodnich i członkiem Związku Osadników. Po wybuchu II wojny światowej przedostał się do Francji, gdzie przebywał do 1941 r. W czasie okupacji Białorusi pracował w niemieckiej administracji Mińska i Borysowa. Za kolaborację z III Rzeszą został w 1945 aresztowany przez NKWD i zesłany do łagru. Po zwolnieniu zamieszkał w Wilnie, gdzie zmarł dwa lata później; http://pl.wikipedia.org/wiki/ Fabian_Jeremicz (dostęp: 6.12.2014). 
Kolejnym posłem, o którym informację sporządzono w Wilnie w 1924 r., był Szymon Rak-Michajłowski ${ }^{69}$. Dzięki ustaleniom Aleksandry Bergman, uzupełnionym przez kolejnych badaczy, jego losy są dość dobrze znane.

Już w okresie nauki w Seminarium Nauczycielskim w Mołodecznie, czyli przed 1904 rokiem, zaangażował się w ruch rosyjskich eserów. Jako nauczyciel w czasie wyborów 1905 r. został wydelegowany do Dumy Państwowej z ramienia środowisk chłopskich.

Według informacji Policji Politycznej w latach 1908-1913 Szymon RakMichajłowski w niczym nie ujawniał swego antypaństwowego nastawienia, co pozostaje w oczywistej sprzeczności z ustaleniami historyków. W roku 1912 uzyskał dyplom Instytutu Pedagogicznego w Teodozji na Krymie i zaczął uczyć ${ }^{70}$. Jeszcze przed wojną światową, w konsekwencji zawarcia znajomości z Arkadiuszem Smoliczem ${ }^{71}$ i Antoniuszem Lewickim wstąpił do „Białoruskiego Zebrania Socjalistycznego". Według ustaleń H. Cimka (2011) Rak-Michajłowski uczestniczył w rewolucji 1905-1907 i 1917 r., w latach 1914-1917 był na froncie, następnie zaś przebywał w Mińsku. Od 1917 r. należał do Białoruskiej Socjalistycznej Hromady, a od października 1917 był członkiem Komitetu Centralnego. Według odnalezionych informacji, służył wówczas w charakterze pisarza „przy jakimś sztabie w Mińsku”72.

69 Szymon Rak-Michajłowski, Сымон Аляксандравіч Рак-Міхайлоўскі, Szyman Rak-Michajłowski (1885-1938) - absolwent Seminarium Nauczycielskiego w Mołodecznie (1904), Instytutu Pedagogicznego w Teodozji (1912), członek BSH (od 1917), po rozłamie w Białoruskiej Partii Socjaldemokratycznej, członek Centralnej Białoruskiej Rady Wojskowej, w Prezydium I Wszechbiałoruskiego Zjazdu, członek Rady BRL, założyciel Białoruskiego Komitetu Narodowego w Wilnie, organizator Towarzystwa Szkoły Białoruskiej, poseł na Sejm Rzeczypospolitej, jeden z liderów BWRH, a od 1931 dyrektor Muzeum Państwowego w Mińsku, aresztowany w 1933 pod zarzutem współpracy z Oddziałem II i rozstrzelany; EM, s. 294; ACz, s. 198-200; DM1, przyp. 29; http://pl.wikipedia.org/wiki/Szymon_Rak-Michaj\%C5\%82owski (dostęp: 30.12.2014).

70 Jego najobszerniejszy jak dotąd biogram, sporządzony w oparciu o źródła archiwalne z zasobu AAN w Warszawie zob. H.Cimek, Białorusini w ruchu rewolucyjnym w II Rzeczypospolitej, w: Kwestia narodowościowa w Polsce $i$ we Włoszech $w$ XX wieku. Wybrane problemy, red. H. Cimek, Rzeszów 2011.

71 Arkadź Smolicz, Аркадзь Антонавіч Смоліч, Arkadź Antonawicz Smolicz (1891-1938) - geograf, kartograf i ekonomista. Ukończył Seminarium Duchowne w Mińsku (1905), Nowoaleksandrowski Instytut Gospodarstwa Wiejskiego w Puławach, studiował na Politechnice Kijowskiej. Członek BSH od 1910, a po jej rozpadzie - Białoruskiej Partii Socjaldemokratycznej. Uczestnik I Zjazdu Wszechbiałoruskiego. Gorący zwolennik ogłoszenia BRL. W połowie lipca 1919 przestrzegał J. Piłsudskiego przed napływem do planowanej Białoruskiej Komisji Wojskowej Rosjan udających Białorusinów. Od połowy lipca 1919 objął tekę wicepremiera w rządzie A. Łuckiewicza. W roku 1920 - kierownik Towarzystwa Szkoły Białoruskiej w Wilnie, skąd wyjechał w 1922 r. do Mińska. W BRSR objął funkcję kierownika oddziału planowania i ekonomiki Ludowego Komitetu Gospodarki Wiejskiej. W 1927 został profesorem na Białoruskim Uniwersytecie Państwowym i w Instytucie Kultury Białoruskiej. Od 1930 represjonowany i w 1938 stracony; ACz, s. 215-218; DM1, przyp. 19; http://pl.wikipedia.org/wiki/Arkad\%C5\%BA_Smolicz (dostęp: 29.12.2014).

72 Był starszym unter-oficerem i chorążym 24. pułku transportowego na Froncie Zachodnim (według innego źródła służył na froncie rumuńskim, gdzie zajmował się agitacją rewolucyjną). 
W 1917 został prezesem Komitetu Wykonawczego Białoruskiej Centralnej Rady Wojskowej w Mińsku i jednym z organizatorów I Wszechbiałoruskiego Kongresu. Niezmiernie ciekawa jest zamieszczona na marginesie biogramu RakMichajłowskiego relacja o konsolidacji wojskowych Białorusinów w roku 1917.

Niespodzianie, zawdzięczając agitacji służących w Armii Rosyjskiej członków „Białoruskiej Grupy Socjalistycznej” wśród wojsk rosyjskich zaczyna się raptownie rozpowszechniać narodowościowy ruch białoruski. Jakby jakaś żywiołowa moc jednoczy wszystkich wojskowych Białorusinów od razu na wszystkich frontach. W pułkach, dywizjonach, korpusach i Armiach w przeciągu krótkiego czasu organizują się „Białoruskie Rady Wojskowe”, które mają za zadanie zjednoczenie wszystkich wojskowych Białorusinów, aby potem, wydzielając ich $\mathrm{z}$ tych oddziałów, w których służyli sformować białoruską formację wojskową.

Nie ma wątpliwości, iż Szymon Rak-Michajłowski był organizatorem i uczestnikiem odbywającego się 18-24 października 1917 r. Zjazdu Białorusinów wojskowych Frontu Zachodniego, który powołał Centralną Białoruską Radę Wojskową (CBRW). Jak wiadomo, w roku 1917 został prezesem Komitetu Wykonawczego Białoruskiej Centralnej Rady Wojskowej w Mińsku. Nader ciekawa jest ocena rzeczywistej roli, jaką - według informatorów Policji Politycznej - w tej Radzie miał odgrywać.

Trafił w skład „CRW” gdzie wybrano go na prezesa, jego, zwyczajnego pisarza sztabowego bez żadnego wykształcenia wojskowego, zawdzięczając temu, że w Rosji już się rozpoczęło panowanie rozbestwionych żołnierzy, a do pomocy mu - w charakterze wice-prezesów przydzielono dobrych bojowych oficerów - W[iaczesława] Adamowicza i Jaroszewicza. W CBRW Rak Michajłowski odgrywał bardzo skromną rolę. Do niczego się nie wtrącał, chętnie na posiedzeniach ustępował swe miejsce wiceprezesom.

Szymon Rak-Michajłowski „trafił również” do tworzącej się w tym samym czasie cywilnej Wielkiej Rady Białoruskiej (WRB), w skład której - oprócz wojskowych - weszli przedstawiciele wszystkich istniejących w tym czasie białoruskich kierunków politycznych. Zadaniem Wielkiej Rady Białoruskiej miało być doprowadzenie do sformowania choć jednej białoruskiej dywizji. Rozmowy na temat organizacji białoruskich formacji wojskowych z dowódcą Frontu Zachodniego gen. Nikołajem Duchoninem w Mohylewie w październiku 1917 r., jak powszechnie wiadomo, nie przyniosły oczekiwanych przez Białorusinów rezultatów. Wyłoniła się paląca potrzeba zwołania Zjazdu Wszechbiałoruskiego i Szymon Rak-Michajłowski aktywnie zaangażował się $\mathrm{w}$ tę pracę.

Charakterystyczne, iż w opracowywanej w 1924 r. w Wilnie notatce nie znalazły się de facto żadne informacje dotyczące znaczącej przecież działalności Szymona Rak-Michajłowskiego w Grodnie w latach 1918-1920. Jak wiadomo, Rak-Michajłowski zaangażował się wówczas w zakładanie szkół ludowych, został 
członkiem Centralnej Rady Szkolnej w Mińsku, w 1919 r. uczył w białoruskim gimnazjum w Grodnie. Był też organizatorem i dyrektorem jednego pierwszych białoruskich seminariów nauczycielskich, które powstało w Borunach w $1921 \mathrm{r}$.

W charakterystyce Rak-Michajłowskiego dominują informacje o jego ówczesnym udziale w Białoruskiej Komisji Wojskowej (BKW), do której był rekomendowany przez Pawła Aleksiuka. Jego aktywność w BKW autor opinii skwitował krótko: „oczywiście podtrzymywał wszelkie żądania eserowskie oraz wypełniał dyrektywy Centralnego Komitetu Eserowskiego z Tomaszem Grybem i Pałutą Bodunową na czele".

Bardzo interesujący (i nakazujący postawienie nowych pytań badawczych) jest akapit dotyczący losów Rak-Michajłowskiego u schyłku lata 1920 r.: „Wraz z całą BKW skierował się do Wołkowyska, a następnie oddzielił się od BKW i trafił nie do Wilna, tylko do Grodna opanowanego wkrótce przez bolszewików”.

Zdziwienie funkcjonariusza Policji Politycznej wzbudził fakt, iż bolszewicy nie aresztowali ani Rak-Michajłowskiego, ani przebywającego również w Grodnie jego przyjaciela, Arkadiusza Smolicza ${ }^{73}$. Smolicz otrzymał posadę Komisarza Wydziału Rolnego, a Rak-Michajłowski bez przeszkód rozpoczął wydawanie białoruskiej gazety „Słowo Białoruskie”. Dalej zaś czytamy, że „wydawnictwa tego zabroniły mu dopiero władze polskie. Wtedy wyjechał do Wilna i w niedługim czasie doprowadził do uruchomienia w Borunach Białoruskiego Seminarium Nauczycielskiego. Po zamknięciu Seminarium na nowo osiadł w Wilnie, gdzie zatrudniony został w I Wileńskim Gimnazjum Białoruskim. Przyjęcie mandatu posła łączył z członkostwem w Wileńskim Komitecie Białoruskim, wiceprezesurą w Białoruskiej Radzie Szkolnej i czynnym zaangażowaniem w prace Białoruskiego Towarzystwa Wydawniczego".

Choć trudno byłoby posądzać autora raportu o ciepłe uczucia w stosunku do opisywanego działacza, to jeszcze dalej możemy przeczytać: „Rak-Michajłowski bezwarunkowo jest człowiekiem honoru, niezmiernie ostrożny i nie awanturnik; jest on zwolennikiem idei stworzenia niezależnej Białorusi w jej granicach etnograficznych. Według ostatnich informacji podobno zgodził się na stworzenie «Socjalistycznej Republiki Rad» wchodzącej w skład Związku Sowieckich Republik Radzieckich”. A nieco dalej: „Jest złym politykiem i nieraz uchylał się od spraw, gdy stawały się nazbyt ostre" ${ }^{\text {". }}$.

73 Innymi przyjaciółmi Rak-Michajłowskiego byli Paszkowicz (bolszewik służący w Mińsku), Kozicz, Kościewicz i Łaginowicz [J. Łohinowicz?].

${ }^{74}$ Po wojnie Rak-Michajłowski przeniósł się do Wilna, gdzie przewodniczył Białoruskiemu Komitetowi Pomocy Ofiarom Wojny, był członkiem Białoruskiego Komitetu Narodowego i Białoruskiego Towarzystwa Wydawniczego. Choć od 1918 należał do Białoruskiej Partii Socjaldemokratycznej, w czasie kampanii wyborczej do Sejmu w 1922 występował jako niezależny socjalista. Jako członek Białoruskiego Klubu Parlamentarnego zasiadał w komisjach: prawniczej, opieki społecznej i inwalidzkiej oraz zdrowia publicznego. Od 24 czerwca 1925 był członkiem i sekretarzem Klubu Poselskiego BWR Hromady, autorem jej statutu, zastępcą prezesa KC, organizatorem Centralnego Sekretariatu i opiekunem wydawnictw tej partii. W 1926 został przyjęty do KPZB. Aresztowany w 1927 i więziony do 1930. W 1931 wyjechał do Mińska i objął tam 
Michał Kochanowicz ${ }^{75}$ (ur. 1882) był również synem chłopskim, absolwentem gimnazjum w Nowogródku oraz fakultetu historyczno-filozoficznego w Charkowie. Po ukończeniu studiów osiadł w Wilnie, gdzie pracował jako nauczyciel szkół średnich. Podobnie jak Jeremicz, ściśle współpracował ze znanymi w Wilnie „Białorusinami nie uznającymi języka białoruskiego” - Sołoniewiczem i Kowalukiem. Według osób znających Kochanowicza był on w tym czasie szeroko znany jako zawzięty reakcjonista podtrzymujący stosunki z tzw. czarną sotnią.

Po ewakuacji w 1915 r. Kochanowicz znalazł się w Mohylewie, gdzie po raz pierwszy „wystąpił jako Białorusin”. Został członkiem i wiceprezesem „Mohylewskiej Rady Białoruskiej”. Równolegle współpracował z oficjalnym pismem „Mogilewskije Izwiestia” [Autor notatki podał tytuł "Mohylewski Wiestnik”].

Po powrocie do Wilna w 1918 r. pracował w „Wileńskiej Radzie Białoruskiej” i deklarował dążenie w utworzenia Państwa Litewsko-Białoruskiego, a także zaangażował się w organizowanie „Pierwszego Gimnazjum Białoruskiego"76, którego został pierwszym dyrektorem. W roku 1923, w wyniku konfliktu z poległym sobie personelem - według informacji PP - wyjechał na stałe do Baranowicz. Według autora odnalezionej opinii, zmuszony został do dymisji z powodu posądzeń o pracę na rzecz bolszewików i rządu sowieckiego. Możliwe jednak, że start w wyborach i przyjęcie mandatu posła Sejmu Ustawodawczego w Warszawie uniemożliwiły mu

stanowiska dyrektora Białoruskiego Muzeum Państwowego i członka Centralnego Komitetu Wykonawczego BSRR. Aresztowany w połowie 1933, a w 1938 stracony. Zrehabilitowany po XX Zjeździe KPZR; zob. H. Cimek, op. cit., s. 27-28.

75 Michaś Kachanowicz, Michał Kochanowicz, ps. M.К-ć, Міхаіл Сілуянавіч Кахановіч, Michaił Siłujanawicz Kachanowicz (1882-1934) - absolwent historii i filozofii Uniwersytetu w Charkowie, nauczyciel w wileńskich gimnazjach. W 1915 uczył w szkole realnej w Mohylewie. Wg EM powierzono mu mandat radnego Mohylewa. W 1917 został redaktorem naczelnym „Mogilewskich Izwiestii”, po rewolucji lutowej był przewodniczącym Białoruskiego Komitetu Narodowego w Mohylewie. Od 1918/1919 przebywał w Wilnie, gdzie związał się z białoruskimi organizacjami kulturalnymi i narodowymi. Pracował jako nauczyciel. Był pierwszym dyrektorem Gimnazjum Białoruskiego w Wilnie (1919-1922). Zajmował się publicystyką, pisując m.in. do „Biełaruskiej Krynicy” i „Biełaruskich Wiedamości”. Był posłem na sejm I kadencji. Formalnie bezpartyjny, a faktycznie związany (wg EM) z radykalnie lewicową frakcją białoruskiego ruchu narodowego. W 1925 zrzekł się mandatu posła i wyjechał do BSRS, gdzie pracował jako redaktor w gazetach „Sawieckaja Biełaruś” i „Sawieckaje budaunictwa”. W sierpniu 1933 aresztowano go pod zarzutem szerzenia białoruskiego nacjonalizmu, a w styczniu 1934 skazano na karę śmierci przez rozstrzelanie (maj 1934) za przynależność do nieistniejącej organizacji „Białoruskie Centrum Narodowe”; EM, s. 290; DM1, przyp. 43; http://pl.wikipedia.org/wiki/Micha\%C5\%82_Kochanowicz (dostęp: 30.12.2014).

${ }^{76}$ Opinia o Kochanowiczu zawiera krytyczny akapit z 1924 o efektach kształcenia w prowadzonej przez niego placówce: „Można śmiało twierdzić, że gimnazjum przez cały czas swego istnienia wychowywało wrogów Polski i zwolenników idei bolszewickiej. Część Uniwersytetu Praskiego, byłych wychowańców Wileńskiego Gimnazjum Białoruskiego, należy do III Związku Studentów (bolszewickiego). Druga część wychowanych przez Kochanowicza maturzystów już od dawna pracuje w Sowieckiej Białorusi, a trzecia - po wsiach białoruskich na Kresach Wschodnich rozpowszechniając wśród włościan idee bolszewickie i wrogi nastrój przeciwko Polsce"; LCVA, fond 51 (Urząd Wojewódzki Wileński), ap. 17, byla 6 . 
dalszą skuteczną kontrolę rozwoju sytuacji w Gimnazjum. Równolegle do działalności w Białoruskim Klubie Poselskim brał czynny udział w pracach Wileńskiego Komitetu Narodowego (skrzydła lewicowego), Centralnej Rady Szkolnej i Zarządu Białoruskiego Towarzystwa Naukowego.

Choć oficjalnie występował jako bezpartyjny, to - zdaniem funkcjonariuszy Policji Państwowej - z wyjątkową przychylnością odnosił się do białoruskich eserów i komunistów. W roku 1924 był zwolennikiem stworzenia Białoruskiej Republiki Sowieckiej w jej granicach etnicznych.

Radosław Ostrowski ${ }^{77}$ (ur. 1887) - nie posłował do Sejmu I kadencji, ale podobnie jak Kochanowicz - był jednym z nielicznych Białorusinów z wyższym

77 Radosław Ostrowski, Radasłaŭ Astroŭski (1887-1976), białoruski publicysta i działacz narodowo-społeczny, polityk i pedagog. W 1907 wydalony z gimnazjum w Słucku za udział w działalności rewolucyjnej. W 1908 wstąpił na Uniwersytet Petersburski na studia matematyczno-fizyczne W 1911 aresztowany, przebywał w więzieniu w Petersburgu i Pskowie, po czym władze carskie nakazały mu osiedlenie się w Prużanie pod nadzorem policji. Uzyskał zgodę (1913) na dokończenie studiów na uniwersytecie w Dorpacie. Pracował następnie jako nauczyciel w szkołach w Częstochowie i w Mińsku. W trakcie I wojny św. przebywał w Rosji. Wykładał (od 1915) w mińskim instytucie pedagogicznym, gdzie uzyskał tytuł profesora. Po rewolucji lutowej został komisarzem powiatowym Rządu Tymczasowego w Słucku. W marcu 1917 wziął udział w Konferencji Organizacji i Partii Białorusi. We wrześniu był organizatorem gimnazjum białoruskiego w Słucku, gdzie nauczał i został pierwszym jego dyrektorem. Należał do Białoruskiej Socjalistycznej Hramady. Wydawał też pismo „Pодны Kрай”. W grudniu 1917 uczestniczył w I Kongresie Wszechbiałoruskim w Mińsku optując za powstaniem niezależnego państwa białoruskiego. Wyjechał na Ukrainę Naddnieprzańską, i wstąpił do Armii Ochotniczej Denikina. W listopadzie-grudniu 1920 brał udział w powstaniu słuckim. Po niepowodzeniu walk przeszedł wraz $\mathrm{z}$ resztkami wojsk białoruskich na polskie terytorium. Wznowił swoją aktywność polityczną wśród Białorusinów mieszkających we wschodniej Polsce. Zatrudniony został przy rozdawnictwie pomocy amerykańskiej. Przez 12 lat (1924-1936) był dyrektorem gimnazjum białoruskiego w Wilnie. W lutym 1924 zainicjował powstanie propolskiego Polsko-Białoruskiego Towarzystwa, ale po jego rozpadzie jeszcze w tym samym roku nawiązał współpracę z nielegalną Komunistyczną Partia Zachodniej Białorusi, której członkiem ostatecznie został w 1926. W 1925 został zastępcą przewodniczącego Białoruskiej Włościańsko-Robotniczej Hromady. Należał też do kierownictwa Towarzystwa Szkoły Białoruskiej, Białoruskiego Towarzystwa Dobroczynności, Białoruskiego Towarzystwa Naukowego i był dyrektorem banku spółdzielczego w Wilnie, przez który przechodziły pieniądze na finansowanie Hromady. W początkach 1927 Ostrowskiego aresztowano, a następnie wydalono na tereny Polski centralnej. Sytuacja zmieniła się gdy w 1928 powrócił do działalności politycznej na rzecz ludności białoruskiej demonstrując zarazem postawę lojalną wobec państwa polskiego. W 1930 wszedł do prezydium Centralnego Związku Białoruskich Kulturalno-Oświatowych oraz Gospodarczych Organizacji i Instytucji (Centrasajuzu). W wyniku nacisku władz administracyjnych od 1936 mieszkał w Łodzi. We wrześniu 1941 przyjechał do Mińska, rozpoczynając organizowanie administracji białoruskiej. Stanął na czele tzw. Nebenbureau. Po miesiącu został zdymisjonowany przez Wilhelma Kube. Pełnił funkcje burmistrza (Briańsk, Smoleńsk, Mohylew). W końcu 1943 został przewodniczącym Białoruskiej Centralnej Rady. W lutym 1944 podpisał odezwę w sprawie utworzenia i mobilizacji do Białoruskiej Obrony Krajowej. Na 2 tygodnie przed wycofaniem się Niemców współorganizował w Mińsku II Kongres Wszechbiałoruski, a po zakończeniu jego obrad wraz z kierownictwem BCR ewakuował się do Rzeszy; EM, s. 294; http://pl.wikipedia.org/wiki/Rados\%C5\%82aw_Ostrowski (dostęp: 6.12.2014). 
wykształceniem. Według odnalezionych informacji urodził się w Nieświeżu. Jedyną informacją o losach Ostrowskiego do jesieni 1920 r., jaką dysponował Okręgowy Urząd Policji Politycznej w Wilnie, było to, że przed wojną uczył w gimnazjum w Słucku i w tymże Słucku otworzył gimnazjum białoruskie, w którym objął stanowisko dyrektora. Szkoła ta została bardzo szybko zlikwidowana przez bolszewików, a Ostrowskiego aresztowano. Wstawiennictwo niezidentyfikowanych działaczy białoruskich sprawiło, że bolszewicy zwolnili go z aresztu. Ostrowski pojechał do Mińska i zaangażował się w ruch eserów, wyraźnie ciążąc ku prawicy tej partii. W trakcie okupacji niemieckiej zerwał kontakty z eserami i - wraz z adwokatem Aleksiukiem $^{78}$ - szukał kontaktu z Niemcami. Nowe informacje o Ostrowskim przynosi ta część raportu, która dotyczy wydarzeń mających miejsce na jesieni 1920 r. „Gdy przy Armii Ochotniczej generała Bałachowicza zorganizowano tzw. Białoruski Komitet Polityczny, który następnie po zajęciu Mozyrza został przekształcony [16 XI 1920] w tymczasowy «Rząd Białoruskiej Republiki Ludowej» [z Wiaczesławem Adamowiczem na czele], Ostrowskiemu zaproponowano tekę Ministra Oświaty. Nie zdążył jednakowoż przyjechać do Mozyrza, gdyż armia ochotnicza pod naciskiem bolszewików musiała się cofnąć na terytorium Polski”.

Pozostaje kwestią domysłu czy Ostrowski nie zdążył, czy nie chciał zdążyć. Faktem jest, że dał dowód osobistej odwagi i poświęcenia dla swej ojczyzny, biorąc udział w powstaniu słuckim. Po jego niepowodzeniu znalazł się na terytorium Polski.

W listopadzie 1920 r. pracował w Brześciu nad Bugiem w „Amerykańskim Komitecie Pomocy Dzieciom” i trzymał się z daleka od polityki. Wileński Narodowy Klub Białoruski wielokrotnie i bez skutku usiłował skłonić Ostrowskiego do startu w wyborach do Sejmu w Warszawie. W listopadzie 1923 r. Ostrowski uległ długotrwałym namowom ks. Stankiewicza i od 1 stycznia 1924 r. objął posadę dyrektora Wileńskiego Gimnazjum Białoruskiego. Jego nominacja miała zostać przyjęta bardzo źle przez towarzyszy w Mińsku. Przyczyn ich niezadowolenia z tej nominacji należałoby szukać w opinii, jaką Ostrowskiemu wydał Oddział Informacyjny w Wilnie na dwa lata przed aresztowaniem go jako członka Hromady:

78 Było co najmniej dwóch Aleksiuków i jedna Aleksiuczanka. Tutaj mowa o Pawle Aleksiuku (1892-?), czołowym zwolenniku filopolskiego odłamu polityków białoruskich i absolwencie Wydziału Prawa Uniwersytetu Petersburskiego, który był jednym z założycieli Białoruskiego Towarzystwa Pomocy Ofiarom Wojny w marcu 1915 w Wilnie; od lutego 1917 był członkiem BSH; pomiędzy marcem a lipcem 1917 pełnił funkcję zastępcy przewodniczącego Białoruskiego Komitetu Narodowego w Mińsku; postulował dokooptowanie do Rady Zjazdu „Rady Polskiej Ziemi Mińskiej” in corpore, co przyjęto z oburzeniem. Wraz z Ramanem Skirmuntem witał na stacji wkraczających do Mińska Niemców, za co został wykluczony z Rady Zjazdu; od lipca 1918 w Sekretariacie Ludowym BRL; w 1919 członek Centralnej Białoruskiej Rady Wileńszczyzny i Grodzieńszczyzny. Od sierpnia 1919 do kwietnia 1920 organizował Białoruską Komisję Wojskową; przewodniczący Białoruskiego Komitetu Politycznego (od września 1920). W latach 20. był adwokatem w Nowogródku i pełnił funkcję wiceprezesa nowogródzkiego oddziału Towarzystwa Szkoły Białoruskiej; DM1, przyp. 66. 
Ostrowski jest człowiekiem o poglądach umiarkowanych, stoi na stanowisku stworzenia „Niezależnej Białoruskiej Republiki Ludowej” lecz w przeciwieństwie do lewych eserów nie chce mieć nic wspólnego z bolszewikami. Oddany jest całkowicie i wyłącznie sprawie szkolnictwa białoruskiego. Jest ostrożny, na wszelkie sprawy zapatruje się bardzo realnie, nie znosi awantur i awanturników, nie poddaje się wpływom postronnym i wytrwale dąży do celu. Obecnie jest jednym z wybitnych członków tzw. stronnictwa ugodowego ${ }^{79}$, stworzonego przez posłów sejmowych Taraszkiewicza i Jeremicza. Stosunek jego do władz polskich jest całkowicie lojalny.

Klaudiusz Duż-Duszewski ${ }^{80}$ - pochodzący z drobnej szlachty rzymski-katolik, w 1912 r. ukończył Wileńską Szkołę Realną, a na przełomie 1917/1918 piotrogrodzką Politechnikę. Ruchem białoruskim w Piotrogrodzie kierowali w tym czasie profesorowie Epinach [Epimach], Szypiło, Wacław Iwanowski i inni. Białoruskie kółko wydawnicze „Zahlanie słonce u nasze okonce” finansowała księżna Magdalena Radziwiłł. Klaudiusz Duż-Duszewski należał - wraz z Bronisławem Taraszkiewiczem, Mikołajem Szyłą, znanym zwolennikiem orientacji propolskiej Pawłem Aleksiukiem i innymi - do dwóch białoruskich kółek: studenckiego i kulturalno-oświatowego.

W roku 1919 przybył do Wilna już jako członek partii socjalrewolucjonistów i wziął udział w Zjeździe Wileńszczyzny i Grodzieńszczyzny (według zapisu funkcjonariusza polskiej Policji Politycznej w „Zjeździe Zachodniej Białorusi” zwołanym w maju 1919 r. „za zgodą Piłsudskiego”) $)^{81}$. Został wybrany na przewodniczącego tego Zjazdu. W dyskusjach i głosowaniu - podobnie jak Tomasz Hryb - prezentował stanowisko zgodne z linią partii socjalrewolucjonistów. Duż-Duszewskiego wybrano na prezesa utworzonej wtedy Centralnej Białoruskiej Rady Wileńszczyzny i Grodzieńszczyzny, jednak bardzo szybko ustąpił z tego stanowiska. W lecie prowadził zajęcia na Białoruskich Kursach Nauczycielskich, a od 1 września 1919 r. pracował w Gimnazjum Białoruskim w Wilnie jako nauczyciel geografii. W tym samym roku został członkiem Białoruskiego Komitetu Narodowego w Wilnie i Białoruskiej Komisji Wojskowej. W 1921 r. wyjechał z żoną na stałe do Kowna, gdzie wszedł do rządu BRL (Łastowskiego). Pozostając w stosunkach z eserami, nie brał udziału w przygotowaniu powstania na Wileńszczyźnie i Grodzieńszczyźnie.

79 W lutym 1924 r. powstało Towarzystwo Polsko-Białoruskie.

${ }^{80}$ Klaudiusz Duż-Duszewski, Клаудзій Дуж-Душэускі (1891-1959). Autor wzoru flagi białoruskiej (pot-krew-łzy). Członek BSH od 1917 r., a od 1918 - Białoruskiej Partii Socjalistów-Rewolucjonistów. Od 1919 członek Białoruskiego Komitetu Narodowego w Wilnie. W tym samym roku został przedstawicielem dyplomatycznym BRL w państwach nadbałtyckich, w 1921 wyemigrował do Kowna, gdzie pracował pomiędzy 1921 a 1930 w urzędach państwowych. Aresztowany przez władze sowieckie, a następnie niemieckie. Przeżył wojnę. Do 1946 był docentem Uniwersytetu Kowieńskiego. Ponownie aresztowany przez władze sowieckie; DM 2, przyp. 146; http://pl.wikipedia.org/wiki/Klaudiusz_Du\%C5\%BC-Duszewski (dostęp: 6.12.2014).

81 Por. J. Gierowska-Kałłaur [oprac.], Dokument XI: Zjazd Białoruski w Wilnie 8-9 czerwca 1919, http://www.sdr-ihpan.edu.pl/files/10_gierowska.pdf (dostęp: 2.01.2015). 
Jak ustalono, „nie podzielał ówczesnego nastroju kowieńskich Białorusinów, będąc z natury człowiekiem umiarkowanym”, a także „cieszył się popularnością wśród drobnych pracowników białoruskich tak nauczycieli jak i innych dzięki usposobieniu i szczeremu oddaniu się sprawie".

Osobą, której poświęcono obszerny i niezbyt pochlebny biogram, był Mikołaj Krasiński $^{82}$ - syn urzędnika „Opieki Szlacheckiej” z Wilejki. Zdekonspirowany przez studentów donosiciel Ochrany, działacz „czarnej sotni”.

Wykształcenie otrzymał w I Gimnazjum w Wilnie, następnie studiował na uniwersytecie w Petersburgu. W czasach studenckich powszechnie podejrzewany był o bliskie stosunki z Ochraną petersburską, gdyż często zdarzało się, że wkrótce po bytności Krasińskiego w jakimś kółku lub organizacji, dokonywano tam rewizji i aresztowań. Jako Białorusin bywał również na wieczorach białoruskich, organizowanych przez kółko białoruskich studentów i studentek. Podejrzewano, że jest zdrajcą, i że doniósł na to kółko do Ochrany, wobec czego niektórzy studenci musieli odpokutować okazane mu zbytnie zaufanie. Niejeden miał zostać zesłany na Sybir, a opinia białoruskich studentów jednogłośnie obarczała za to winą Krasińskiego.

Należąc do „czarnej sotni”" ${ }^{3}$, Krasiński brał udział we wszystkich rosyjskich manifestacjach patriotycznych, za co miał otrzymywać zapomogi materialne. Studenci dobrze znający Krasińskiego mówili o nim jako o człowieku pozbawionym wszelkich zasad moralnych, bezideowym, w nic nie wierzącym, gotowym służyć każdemu, byle mu tylko za to płacono.

W chwili wybuchu rewolucji rosyjskiej dokonała się w nim diametralna przemiana - dawny czarnoseciniec stał się bolszewikiem, zaciętym komunistą, a nawet komisarzem. Policja Polityczna miała podstawy, by przypuszczać, że Krasiński został posłany do Wilna przez agenturę bolszewicką w celach politycznych. Te przypuszczenia potwierdzał fakt, iż zarówno on jak i towarzysząca mu siostra ostentacyjnie chwalili warunki życia w Sowdepji. Po przybyciu do Wilna Krasiński zbliżył się do Łuckiewicza, Karabacza, Prokulewicza, Kraskowskiego, Kochanowicza oraz Jeremicza i zaczął pracować w wileńskim Białoruskim Komitecie Narodowym. Został nauczycielem, a potem inspektorem w Prawosławnym Seminarium Duchownym.

Powszechnie postrzegany jako ateista i nihilista, wykorzystując osobistą zażyłość z rektorem seminarium Bohdanowiczem, z polecenia Antona Łuckiewicza „zainstalował się” w Prawosławnym Konsystorzu Duchownym z ramienia wileńskiego Białoruskiego Komitetu Narodowego. Według ustaleń Policji Politycznej aktywnie działał w środowisku duchowieństwa prawosławnego, uprawiał agitację

${ }^{82}$ Mikołaj Krasiński (1891-1938), w latach 1922-1924 nauczyciel Białoruskiego Gimnazjum w Wilnie [DM2, przyp. 278]]. Obszerna o nim opinia przechowywana jest w LCVA, fond 51 (Urząd Wojewódzki Wileński), ap. 17, byla 6, lap. 30-31.

83 Ruch zwany czarną sotnią, do którego należały m.in. Związek Narodu Rosyjskiego i Związek Michała Archanioła. 
antypaństwową o charakterze bolszewickim. Akcję prowadził zarówno w Prawosławnym Konsystorzu Duchownym, jak i w Prawosławnym Seminarium Duchownym i dopiero interwencja arcybiskupa Teodozjusza zmusiła go do ustąpienia.

Podobnie jak rektor Bohdanowicz był jawnym zwolennikiem bojkotu wyborów do sejmu warszawskiego. Pomimo tego pracował na rzecz Bloku Mniejszości Narodowych w Centralnym Komitecie Wyborczym w Wilnie.

Według policyjnej opinii Krasiński zatrudnił się w Wileńskim Gimnazjum Białoruskim w okresie pełnienia funkcji dyrektora przez Trepkę, człowieka znanego ze słabej woli. Po krótkim czasie to Krasiński zdobył tam głos decydujący, a Trepko miał mu we wszystkim ulegać ${ }^{84}$. W chwili powstawania omawianej opinii Krasiński należał do wileńskiego Białoruskiego Komitetu Narodowego, a przy tym był członkiem Centralnej Rady Szkolnej, Zarządu Białoruskiego Kółka Dramatycznego i „Białoruskiego Zebrania Obywatelskiego” („Białoruskoje Hramadzanskoje Sobranije").

Siostra Michała Krasińskiego, Ksenia, stała się przedmiotem żywego zainteresowania Józefa Lohinowicza ${ }^{85}$. O Józefie Łohinowiczu (wg informacji PP ur. 1896) ${ }^{86} \mathrm{w} 1924 \mathrm{r}$. w Wilnie wiedziano tyle, że był katolikiem i starym eserem, który całą wojnę spędził na froncie jako prosty żołnierz, i że brał udział w powstaniu słuckim, po klęsce którego znalazł się na terytorium Polski. W maju $1921 \mathrm{r}$. zwolnił się z obozu internowanych i przyjechał do Wilna, gdzie zaangażował się u Pawła Aleksiuka ${ }^{87}$ w pracę „Biełaruskaj Nacjonalnej «Suwiazi»”. Był korektorem

${ }^{84}$ Absolwenci tej szkoły - według informacji Policji Politycznej - otrzymali posady w Sowieckiej Białorusi, studiowali na Białoruskim Uniwersytecie Państwowym i na Politechnice Mińskiej, a także w Pradze, i z reguły należeli do „trzeciego Związku Studentów (bolszewickiego)”.

${ }^{85}$ Wg ustaleń H. Cimka Łohinowicz w lutym 1936 przyjechał z Kopenhagi do Moskwy, gdzie został niesłusznie oskarżony, uwięziony i ostatecznie stracony w roku 1940. Zob. H. Cimek, op. cit., s. 15; S. Zachariasz, Józef Łohinowicz, „Z Pola walki” 3 (1961), s. 212; AB, s. 61. Według wcześniejszych ustaleń Doroty Michaluk Łohinowicz w latach 1922-1923 był członkiem Białoruskiego Komitetu Narodowego w Wilnie a od grudnia 1923, czyli od chwili połączenia BOR z KPZB, pozostawał w składzie CK KPZB. Został aresztowany przez władze polskie z powodu swojego uczestnictwa w V Kongresie Kominternu w Moskwie i zbiegł do BSRS, gdzie pracował w ruchu komunistycznym na terenie Zachodniej Białorusi. W 1936 aresztowany pod zarzutem współpracy z polską policją polityczną. W 1939 został skazany na śmierć. W kwietniu 1940 zmarł w więzieniu; DM2, przyp. 281.

${ }^{86}$ Urząd Komisarza Rządu na m. Wilno L.dz. 2077/I/24/Ag.inf, Wilno, 4.04.1924. Do Oddziału Informacyjnego w.m. Łohinowicz Józef. Opinia. [Podp. M. Olendzki, kierownik Agent. Inf.] LCVA, fond 51 (Urząd Wojewódzki Wileński), ap. 17, byla 6, lap. 20-20v.

87 Jak ustaliła Joanna Januszewska-Jurkiewicz zahamowanie działalności Związku Krajowego w okresie Litwy Środkowej nastąpiło w wyniku aresztowania Pawła Aleksiuka i wywiezienia go z Wilna. Kancelaria Cywilna Naczelnego Dowódcy Wojsk Litwy Środkowej występowała z wnioskiem o natychmiastowe uwolnienie go. Według znacznie późniejszej relacji Komendy Policji Politycznej na m. Wilno (LCVA, f. 15, ap. 2, b. 232, k. 37: Sprawozdanie z ruchu politycznego i ekonomiczno-społecznego w Wilnie za marzec 1925) Aleksiuk, w związku z działalnością w Białoruskiej Komisji Wojskowej „miał jakieś niejasne sprawy finansowe, siedział w więzieniu w Warszawie, skąd za wstawiennictwem Bałachowicza był wypuszczony”. Jak ustaliła J. Januszewska-Jurkiewicz 
białoruskiego tygodnika „Jedność", dorywczo pracował też u komornika Umiastowskiego. Zdecydowanie nie były to informacje precyzyjne. Jak ustalili S. Zachariasz i H. Cimek w rzeczywistości Łohinowicz urodził się w 1891 r. i w roku 1924 miał już 35 lat. Działał pod różnymi nazwiskami - m. in. jako Paweł Korczyk syn Kajetana, bezrolnego chłopa białoruskiego. W latach 1910-1912 należał do Białoruskiej Socjalistycznej Hromady. Po rewolucji październikowej wstąpił do partii socjalrewolucjonistów (eserów). Od 1922 r. był jednym z przywódców Białoruskiej Organizacji Rewolucyjnej, która 30 grudnia 1923 r. połączyła się z KPZB. Został wówczas członkiem KC KPZB, a nieco później (od 1924) - członkiem jej Biura Politycznego. Później był także członkiem KC KPP (1925-1936: w latach 19251929 nawet członkiem Biura Politycznego KC KPP, a 1929-1933 zastępcą członka BP KC KPP).

Żaden $\mathrm{z}$ autorów biogramów ${ }^{88}$ nie podaje jednak kilku istotnych faktów z życiorysu Łohinowicza. Według informacji uzyskanych przez policję polityczną $\mathrm{w}$ Wilnie, podczas wyborów do Sejmu w Warszawie jesienią 1922 r. Łohinowicz zatrudnił się jako sekretarz w Centralnym Białoruskim Komitecie Wyborczym, stając się w krótkim czasie jego faktycznym kierownikiem. Nowo wybrani posłowie docenili jego zaangażowanie i zatrudnili go jako pomocnika sekretarza w Sekretariacie Wileńskiego Białoruskiego Klubu. Oficjalnie sekretarzem był ks. Bolesław DruckiPodbereski, ale de facto wszystkie jego obowiązki pełnił J. Łohinowicz, który dodatkowo przejął po Rodziewiczu ${ }^{89}$ obowiązki redaktorskie i pod pseudonimem „Kumelgan” publikował artykuły m.in. w gazecie „Nowe Życie”, której 13 numerów ukazało się pod jego redakcją w okresie od 3 marca do 21 maja $1923 \mathrm{r}$. Jednocześnie Łohinowicz był sekretarzem Białoruskiego Komitetu Narodowego i członkiem innych, mniej istotnych stowarzyszeń.

Łohinowicz mieszkał w samym centrum Wilna, początkowo prowadząc skromne życie starego kawalera. Był wtedy człowiekiem „miękkim, ale akuratnym i zdecydowanym, posępnym i małomównym”. Zmiana nastąpiła w chwili objęcia nowych obowiązków - teraz miał pieniądze, zaczął kupować sobie modną odzież, chodzić do kawiarni, udzielać się towarzysko. Olendzki sugeruje, iż zmiana trybu i poziomu życia związana była z kontaktem z Sowietami. Odnoszę jednak wrażenie, że Łohinowicz, abstrahując od swoich poglądów politycznych i powiązań

ważnym czynnikiem w koncepcjach Aleksiuka była niechęć do Rosji, co odróżniało go od znakomitej większości współczesnych mu działaczy białoruskich. J. Januszewska-Jurkiewicz, Dwie „krajowe” inicjatywy białoruskie na Litwie Środkowej; http://kamunikat.fontel.net/www/czasopisy/ bzh/16/16kryn_januszewska.htm (dostęp: 6.12.2014).

88 S. Zachariasz, op. cit., s. 212; A. Bergman, Sprawy białoruskie..., s. 61.

89 Leapold Rodziewicz, Леапольд Родзевіч (1895-1938) - białoruski pisarz i polityk. Redaktor naczelny czasopism „Nasza Buduczynia” i „Biełaruski Zwon” (1922-1923) oraz „Nasz Sciah Balszawik” (1925-1934). Rozstrzelany w trakcie stalinowskich „czystek”. Początkowo związany z futuryzmem, napisał m.in. dramat Błudniki (1912), następnie tworzył wiersze wspierające rewolucyjne przemiany wprowadzane przez bolszewików, wydane m.in. w zbiorze Biełaruś (1922); http://portalwiedzy.onet.pl/11344,,,,rodziewicz_leapold,haslo.html (dostęp: 6.12.2014). 
finansowych, po prostu zakochał się w pannie Kseni Krasińskiej. Poglądy tej panny i jej brata niewątpliwie wpłynęły na Łohinowicza, o którym Olendzki napisał w kwietniu 1924:

Ostatnimi czasy wychwala taktykę sowietów w Mińsku, jak również głosi, iż niepodległość i wolność ludu białoruskiego mogą przyjść tylko za pomocą Sowieckiej Białorusi. Sprawę Kresów traktuje jako „okupację” ze strony Polaków i [uważa], że nienawistne Rządy Polskie w Wileńszczyźnie mogą być obalone tylko podczas polskiej wewnętrznej waśni, czy też w chwili zatargów zewnętrznych. Obecnie zaś zbrojne powstanie jest niemożliwe i według niego należy wśród Białorusinów prowadzić pracę kulturalnooświatową, uwiadamiając naród białoruski.

Odnalezione materiały Policji Politycznej nie zawierają zbyt wielu informacji o pozostałych działaczach białoruskich, a szczątkowe dane na ich temat są albo niepochlebne, albo zabawne.

Wsiewołod Bildziukiewicz ${ }^{90}$ do wojny był znanym $\mathrm{z}$ łapownictwa urzędnikiem na kolei, prawicowcem i nacjonalistą rosyjskim. Po przyjeździe do Wilna zajął się dostawą produktów dla wojska. Jednocześnie nawiązał znajomość z działaczami białoruskimi i zapisał się do Klubu Białoruskiego, gdzie wybrano go starszym klubu. Był znanym organizatorem gier hazardowych. Ujawniono, że oszukiwał przy grze w lotto, w związku z czym został zmuszony do opuszczenia klubu. Nie należał już później do partii politycznych.

Arseniusz Konczewski ${ }^{91}$ był bratem znanego (zmarłego w 1924 r.) kooperatysty białoruskiego. Po powrocie z Rosji (w 1919 r.) w roku 1921 wstąpił do II klasy gimnazjum białoruskiego w Wilnie, lecz wkrótce zaniechał kształcenia się i podjął pracę w Związku Kooperatyw Białoruskich. Należał do obozu aktywnych socjalistów i często bywał na ich zebraniach. Na jesieni 1923 r. wybrano go do Prezydium Białoruskiej Centralnej Rady Szkolnej, powierzając mu stanowisko sekretarza. Według informacji pozyskanych przez Policję Polityczną „szczególnie blisko był zaprzyjaźniony z dziennikarzem białoruskim Józefem Łohinowiczem”.

${ }^{90}$ Urząd Komisarza Rządu na m. Wilno L.dz. 2080/I/24/Ag.inf, Wilno, 4.04.1924. Do Oddziału Informacyjnego w.m. r. Bildziukiewicz Wsiewołod. Opinia [Podp. M. Olendzki, kierownik Agent. Inf.] LCVA, fond 51 (Urząd Wojewódzki Wileński), ap. 17, byla 6, lap. 18.

91 Arseniusz Konczewski (?-1931), członek Komunistycznej Partii Zachodniej Białorusi i Towarzystwa Szkoły Białoruskiej, działacz białoruski na terenie Wolnego Miasta Gdańska. Zginął w Morzu Czarnym w 1931. Zob. H. Głogowska, Białorusini na Wybrzeżu Gdańskim, Toruń 2003, s. 262. Zob. też „Lista członków KPP i KPZB”. http://www.google.pl/url?sa=t\&rct=j\&q=\& esrc $=s \&$ source $=$ web \&cd $=5 \& v e d=0$ CDUQFjAE\&url=http\%3A\%2F\%2Fwww.gabrielesimoncini. it\%2FPublications\%2FDocs\%2FList\%2520KPP.rtf\&ei=0taEVLa3OYHmywOxgYK4Dw\&usg=AF QjCNGIXAeZaKtLXMCgO2NFLSj773ejg\&bvm=bv.80642063,d.d24 (dostęp: 6.12.2014).Urząd Komisarza Rządu na m. Wilno L.dz. 2077/I/24/Ag. inf, Wilno, 4.04.1924. Do Oddziału Informacyjnego w.m. Konczewski. Opinia [Podp. M. Olendzki, kierownik Agent. Inf.], LCVA, fond 51 (Urząd Wojewódzki Wileński), ap. 17, byla 6, lap. 22. 
Michał Pietkiewicz ${ }^{92}$ (ur. 5 XI 1885 we wsi Zanarocz, w powiecie święciańskim) był „prawosławnym kawalerem usposobienia wesołego, w pełnieniu swych obowiązków sumiennym i akuratnym, chociaż zdradzał pewną niechęć do pracy".

Uczył się początkowo w Borunach, następnie w Instytucie Nauczycielskim w Wilnie. Jako nauczyciel pracował już w roku 1902, czyli w wieku lat siedemnastu. W latach 1920-1921 uczył w jednej z białoruskich szkól ludowych w Wilnie. W roku 1924 był nauczycielem białoruskiej szkoły powszechnej przy ul. Ostrobramskiej 9. W listopadzie 1923 r. wybrano go do Prezydium Rady Szkolnej - jako wiceprezesa. „Z rozmów prywatnych wynika nieprzychylny stosunek wzg[lędem] państwowości polskiej, [że] nie spodziewa się [ze strony polskiej] naprawy polityki, taktyki i stosunku do Białorusinów. Charakteryzuje go przychylny stosunek do Rosji Sowieckiej. Przystąpił [ostatnio?] do grupy działaczy białoruskich - sympatyków Białorusi Sowieckiej”.

Franciszek Pietkiewicz ${ }^{93}$ był wyznania rzymskokatolickiego; rozpoczął studia medyczne na Uniwersytecie Stefana Batorego w Wilnie. Był człowiekiem energicznym i miał się dać poznać jako „zawzięty Białorusin”. W trakcie pobytu w Wilnie „ocierał się w sferach najbardziej wpływowych Białorusinów orientacji katolickiej (ks. Stankiewicz, Trepko i inni), do której i sam należał”. W opinii czytamy dalej: „Wtarł się do Białoruskiego Komitetu Pomocy Ofiarom Wojny, został też wybrany do Komitetu Narodowego. Charakteryzowały go poglądy prawicowe. Dowodził, że bez burżuazji Białoruś nie pozyska zdrowego społeczeństwa i upragnionej mocy, stał po stronie burżuazji”.

Jesienią 1923 r. Pietkiewicz wyjechał do Pragi razem z młodszym bratem Wacławem, uczniem 8-ej klasy Gimnazjum Białoruskiego w Wilnie. W Pradze wstąpił na uniwersytet, dołączył do prawicowego odłamu studentów, otrzymał dla siebie i brata stypendium, wśród studentów praskich miał opinię faszysty.

Włodzimierz Samojło ${ }^{94}$ przebywał w Wilnie prawie przez całe swoje życie. Był synem bogatych rodziców, studiował starożytną literaturę rzymską i filozofię. Zaangażował się w życie polityczne i społeczne - był członkiem rosyjskiej partii kadetów, współpracownikiem gazety białoruskiej i członkiem Komitetu

92 Urząd Komisarza Rządu na m. Wilno L.dz. 2079/I/24/Ag.inf, Wilno, 4.04.1924. Do Oddziału Informacyjnego w.m. Pietkiewicz Michał. Informacje [Podp. M. Olendzki, kierownik Agent. Inf.] LCVA, fond 51 (Urząd Wojewódzki Wileński), ap. 17, byla 6, lap. 14.

93 Urząd Komisarza Rządu na m. Wilno L.dz. 3973/I/24/Ag.inf, Wilno, 3.06.1924. Do Oddziału Informacyjnego w.m. Pietkiewicz Franciszek. Informacje [Podp. M. Olendzki] LCVA, fond 51 (Urząd Wojewódzki Wileński), ap. 17, byla 6, lap. 13.

94 Włodzimierz Samojło-Sulima (ps. Czemier, Sulima) (1878-1941) - publicysta, krytyk literacki (rodzice: Iwan Samojło i Augusta Nabokow). Zob. A. Bergman, Włodzimierz Samojło-Sulima wobec kwestii białoruskiej w Polsce międzywojennej, „Przegląd Historyczny” 74 (1983), nr 4, s. 653-676. 
Narodowego. W rosyjskiej partii kadetów Samojło pozostawał do ostatniej chwili. Szczególną czcią otaczać miał Milukowa, którego podobiznę miał zawsze wyeksponowaną w swoim w mieszkaniu. Jakiś czas wykładał łacinę w gimnazjum Wellera, skąd został wydalony za intrygi.

W 1920 r. wydawał gazetę rosyjską „Wilenskaja Riecz”, którą subsydiowali Mejtik i Kołtynowicz. Wydawanie gazety pochłaniało poważne kwoty, a ona nie przynosiła dochodu i po wyjściu 100 numerów przestała istnieć.

Jako sekretarz Centralnego Białoruskiego Komitetu Wyborczego w wyborach do Sejmu i Senatu odegrał znaczną rolę w ruchu białoruskim, odnawiając znajomość z działaczami poznanymi w 1917 r. Pisał po rosyjsku, a jego artykuły były tłumaczone na białoruski przez Kościewicza lub Szeleszko. Cechą charakterystyczną Włodzimierza Samojło miała być pycha. W 1924 r. znalazł się w trudnym położeniu materialnym i w tym właśnie autor informacji upatrywał przyczyn zmiany zapatrywań i poglądów Samojły, który zaczął pisywać artykuły o zabarwieniu komunistycznym ${ }^{95}$.

Na koniec - informacja o Żydzie Kleckinie ${ }^{96}$ :

Stosunki Kleckina (właściciela drukarni) z Białorusinami rozpoczęły się jeszcze podczas okupacji niemieckiej (gazeta „Homon”). W latach 1920-1921 u Kleckina drukują się książki i podręczniki białoruskie, wydawane przez Białoruskie Towarzystwo Wydawnicze. W roku 1922 pomiędzy Kleckinem a [Rak]-Michajłowskim jako przedstawicielem Białoruskiego Towarzystwa Wydawniczego została zawarta umowa - Kleckin drukuje na swój koszt książki, otrzymując ze sprzedaży odpowiedni odsetek. Drukowane u Kleckina książki przewożone były częściowo do Białorusi, bo w Polsce nie było na nie popytu. W Białorusi sowieckiej - zapotrzebowanie na nie jest wielkie. [...] Przez Kleckina są przesyłane z Mińska do Polski książki tam drukowane" 97.

Genezy bardzo bliskich i dobrych stosunków Białorusinów z Kleckinem funkcjonariusz polskiej Policji Politycznej dopatrywał się w fakcie, iż Kleckin miał być krewnym żony Łuckiewicza.

Bez względu na genezę tych dobrych stosunków jest jasne, że Kleckin, według informacji policji, czyli Agentury Informacyjnej, jako faktyczny posiadacz drukarni - jednej w Wilnie, a drugiej prawdopodobnie w Mińsku - był łącznikiem Wileńskiego Komitetu Białoruskiego z komunistami mińskimi. Pracownik polskiej agentury informacyjnej podsumował to następująco: „Kleckin jest zmuszony do utrzymywania stosunków z Białorusią Sowiecką, bo ma tam majętności”.

95 Urząd Komisarza Rządu na m. Wilno L.dz. 2078/I/24/Ag.inf, Wilno, 4.04.1924. Do Oddziału Informacyjnego w.m. Samojło Włodzimierz. Opinia [Podp. M. Olendzki, kierownik Agent. Inf.], lap. LCVA, fond 51 (Urząd Wojewódzki Wileński), ap. 17, byla 6, lap.16-16v.

96 Urząd Komisarza Rządu na m. Wilno. Agentura Informacyjna L.dz 4434/I/24, Wilno, 14.06.1924. Tajne Raport M. Olendzkiego, Kierownika Agentury LCVA, fond 51 (Urząd Wojewódzki Wileński), ap. 17 , byla 6 , lap. 1 .

97 Ibidem. 
Trudno komentować nieznane dotychczas informacje biograficzne zawarte $\mathrm{w}$ policyjnych opiniach, albowiem muszą być one jeszcze zweryfikowane $\mathrm{w}$ toku dalszych kwerend archiwalnych, co - nie ukrywajmy - może trwać latami. Uważam, że dotychczasowych ustaleń danych biograficznych działaczy białoruskich, nawet postaci pierwszoplanowych, w żadnym wypadku nie można uznać za ostateczne. Cząstkowe dane przedstawione $w$ tej prezentacji rzucają zupełnie inne światło na motywacje i rolę niektórych działaczy, które nieraz znamy wyłącznie z ich własnych pamiętników spisanych na emigracji (Rahula).

Oddział informacyjny, zgodnie ze swoją nazwą, zajmował się na przełomie lat 1923 i 1924 wyłącznie zbieraniem informacji oraz ich analizą i opracowaniem. Nie ma podstaw do stwierdzenia, iż w jakikolwiek sposób moderował sytuację na kontrolowanym przez siebie terenie. Dostrzec można również brak elementarnej wiedzy pracowników tej agentury na temat wypadków z lat 1919-1920, a także poczucie olbrzymiego zagrożenia własnego państwa po marcu $1923 \mathrm{r}$.

Można jednak pokusić się o próbę odpowiedzi na pytanie, jakie było nastawienie wileńskich funkcjonariuszy polskiej służby bezpieczeństwa do konkretnych działaczy ruchu białoruskiego w roku 1924. Na pewno nie było aż tak negatywne, jak to $\mathrm{w}$ literaturze przyjmowano dotychczas.

Nie rozstrzygając, czy jest to wynikiem niekompetencji pracowników polskiego aparatu bezpieczeństwa, konsekwencją złej organizacji ich pracy, czy po prostu ich „ludzkiej” życzliwości dla ruchu białoruskiego, dostrzegam w prezentowanych tu opiniach dużą dozę empatii w stosunku do poszczególnych działaczy białoruskich.

Najciekawiej jednak prezentuje się - w mikroskali - obraz środowiska działaczy białoruskich wyłaniający się z odnalezionych i omówionych tu 15 opinii.

Dzielił tych ludzi nie tylko wiek, pochodzenie i droga życiowa, bo - według ustaleń PP w Wilnie - ich postępowaniem kierowały zupełnie różne motywy.

Do najstarszych należeli Samojło (ur. 1878), Rahula (ur. 1879), Krasiński (ur. 1880) i Kochanowicz (ur. 1882). Pomimo istotnych różnic w pochodzeniu Samojło i Krasiński wywodzili się z elity mieszkańców tych ziem - żaden z nich nie był zwolennikiem powstania niezależnego i suwerennego państwa białoruskiego. Wszyscy usiłowali w sposób możliwie komfortowy zaplanować swą własną karierę życiową. Nauczyciele Rahula, Krasiński i Kochanowicz konsekwentnie związali się z systemem sowieckim, Samojło dołączył do nich w okresie późniejszym ze względów - wydaje się - czysto pragmatycznych.

Młodsze nieco pokolenie reprezentowali pochodzący z drobnej szlachty Łuckiewicz (ur. 1884) oraz Duż-Duszewski (ur. 1891), a także nauczyciele Rak-Michajłowski (ur. 1885) i Ostrowski (ur. 1887). Wszyscy wymienieni mieli wyższe wykształcenie, wszyscy też zyskali w oczach funkcjonariuszy PP opinie ludzi w wysokim stopniu ideowych.

Do ich grupy wiekowej należeli też dwaj chłopscy synowie - ludzie o nieporównanie niższych kwalifikacjach zawodowych - Mamońko i Jeremicz. Ten pierwszy (ur. 1889) w czasie swojej służby wojskowej w Kownie przeszedł w 1905 roku 
swego rodzaju „akademię terroryzmu” socjalrewolucjonistów rosyjskich. Ten drugi (ur. 1891) znalazł się początkowo pod wpływem czarnosecińców, co zaważyło na jego „karierze” - pomimo radykalnego przeorientowania się na bolszewizm w chwili, gdy dotychczasowi „tutorzy” zniknęli ze sceny politycznej.

\section{Leading Belarusian activists in the light of information of the Governmental Commissar for the City of Vilnius in 1924}

\section{Abstract}

Under specific circumstances of northern-eastern lands in 1923-1924, the Department of Security (Information Agency) of the Ministry of Foreign Affairs in Warsaw addressed in the autumn of 1923 a question to the Commissar of the Government in Vilnius about leading Belarusian activists in the city. In the papers left by the governmental commissar in the city of Vilnius the author of the article found opinions on fifteen leading Belarusian - not only from Vilnius - activists: Vsevolod Bildziukiewicz, Klaudiusz Duż-Duszewski, Fabian Jeremicz, Michał Kochanowicz, Arseniusz Konczewski, Michał Krasiński, Józef Łohinowicz, Anton Luckevitch, Jazep Mamońko, Radosław Ostrowski, Michał and Franciszek Pietkiewicz, Basil Rahulia [Ragulia], Szymon Rak-Michajłowski and Włodzimierz Samojło. This is supplemented by the information about the Jew Boris Kleckin, who supported the Belarusian movement in Vilnius. In fact, confidents did not inform about actual events, but their stories written down by the employees of the Commissar Office shed new light on the developments of the early $20^{\text {th }}$ century, with special emphasis on personal data from the time of the First All-Belarusian Congress (a congress of Belarusian political organisations and groups held in Minsk in December of 1917). The importance of this information is vital also for other reasons, since it makes it possible for us to put forward a thesis that some of Belarusian leaders deliberately compromised others Belarusians (mainly Mamońko) for their own benefits in current political Belarusian-Belarusian controversies. These sixteen opinions surprise us, contrary to a common view, with their evident empathic and sympathetic attitude of functionaries of the Polish Information Agency in Vilnius towards a majority of described figures (including the Jew Boris Kleckin).

\section{Образы ведущих белорусских деятелей в свете сообщений Управления Комиссара Правительства для города Вильно в 1924 г.}

\section{Аннотация}

В специфической политической обстановке, царствующей на северо-восточных землях в 1923-1924 гг. Департамент безопасности (Информационное отделение) Министерства внутренних дел в Варшаве осенью 1923 г. направил запрос к Делегату Правительства в Вильно об предоставлении информации на тему ведущих виленских белорусских деятелей. В наследии Делегата Правительства в Вильно автор работы нашла характеристики пятнадцати, не только виленских, белорусских деятелей: Всеволода Бильдзюкевича, Клавдия Дуж-Душевского, Фабиана Яремича, Михаила Кохановича, Арсения Кончевского, Михаила Красинского, Юзефа Логиновича, Антона Луцкевича, Юзефа Мамоньки, Радослава Островского, Михиала и Франтишка Петкевичей, Василия Рагули, Сымона Рак-Михайловского и Владимира Самойло. К ним было добавлено сообщение о поддерживающем белорусское движение в Вильно еврее Клецкине. 
Агенты не сообщали, в принципе, никакой информации, касающейся текущих событий, зато их рассказы, записанные чиновниками, бросают новый свет на события, начиная с начала столетия, с особенным учетом персональной информации времен Первого Всебелорусского съезда (XII 1917). Ценность этих сообщений - существенна также по другим соображениям. Она позволяет выдвинуть тезис, что часть белорусских лидеров благодаря подставным информаторам белорусам намеренно компрометировала других белорусов (главным образом Мамоньки) для нужд своих текущих белорусско-белорусских споров.

Найденные шестнадцать характеристик - неожиданны, наперекор повсеместно царствующему мнению, из-за исполненного эмпатии и доброжелательности отношения чиновников польской Информационной службы в Вильно к большинству описываемых лиц (включая еврея Клецкина).

\section{Bibliografia}

\section{Źródła archiwalne:}

Archiwum Akt Nowych w Warszawie (AAN), Ministerstwo Wyznań Religijnych i Oświaty, sygn. 1062

Zespół Policji Politycznej z Wilna, sygn. 7.

Lietuvos Centrinis Valstybas Archivas w Wilnie (LCVA), Urząd Wojewódzki Wileński, ap. 17, byla 5 i 6

Urząd Komisarza Rządu na miasto Wilno, ap. 2, byla 232

\section{Źródła drukowane:}

Ustawa z 22 grudnia 1925 r. w sprawie utworzenia województwa wileńskiego, Dz.U. z 1926 r., nr 6, poz. 29

Ustawa o objęciu władzy państwowej nad Ziemią Wileńską, Dz.U. z. 1922 r., nr 26, poz. 213 http://www.yale.edu/annals/Chase/Documents/doc20chapt4.htm

https://www.senat.edu.pl/senat/senatorowie-1922-1939/senatorowie-ii-rp

Ragula W., Wspaminy, NY 1957 (reprint: 1993)

\section{Opracowania:}

Bergman A., Rzecz o Bronisławie Taraszkiewiczu, Warszawa 1977

Bergman A., Sprawy białoruskie w II Rzeczypospolitej, Warszawa 1984

Bergman A., Włodzimierz Samojło-Sulima wobec kwestii białoruskiej w Polsce międzywojennej, „Przegląd Historyczny” 74 (1983), nr 4, s. 653- 676

Cichoracki P., Stołpce-Łowcza-Leśna 1924: II Rzeczpospolita wobec najpoważniejszych incydentów zbrojnych $w$ województwach północno-wschodnich, Łomianki 2012

Cimek H., Białorusini w ruchu rewolucyjnym w II Rzeczypospolitej, w: Kwestia narodowościowa w Polsce $i$ we Włoszech w XX wieku. Wybrane problemy, red. H. Cimek, Rzeszów 2011

Gierowska-Kałłaur J., Kwestia dostępu odradzającego się państwa polskiego do Morza Bałtyckiego a interesy Niemiec, w: Między historia politycznq a historia społeczną. Księga Jubileuszowa ofiarowana Profesorowi Andrzejowi Skrzypkowi w siedemdziesięciolecie urodzin, red. J. Gołota, Pułtusk-Olsztyn-Ostrołęka-Warszawa 2014, s. 64-81 
Gierowska-Kałłaur J., Zarząd Cywilny Ziem Wschodnich 19 lutego 1919 - 9 września 1920, Warszawa 2003

Głogowska H., Białorusini na Wybrzeżu Gdańskim, Toruń 2003

Głogowska H., Los białoruskiego posła Sergiusza Baranowa, „Białoruskie Zeszyty Historyczne”, 1995, z. 2, s. $146-159$

Gomółka K., Białorusini w II Rzeczpospolitej, Gdańsk 1992

Grzybowski J., Pogoń między Orłem Białym, Swastyka i Czerwoną Gwiazdą: białoruski ruch niepodległościowy w latach 1939-1956, Warszawa 2011

Januszewska-Jurkiewicz J. [oprac.], Raport atamana Tymoteusza Chwiedoszczeni dotyczacy działalności partyzanckiej na terenie Białorusi sowieckiej w okresie 10-29 czerwca 1921 r., „Białoruskie Zeszyty Historyczne” 14 (2000)

Januszewska-Jurkiewicz J., Dwie „krajowe” inicjatywy białoruskie na Litwie Środkowej, „Białoruskie Zeszyty Historyczne" 16 (2001), s. 197-218

Januszewska-Jurkiewicz J., Przyczynek do losów przywódców „Zielonego Dębu” w świetle sprawozdań Policji Politycznej w Wilnie z lat 1923-1936, „Białoruskie Zeszyty Historyczne” 15 (2001), s. 220-228

Kietliński M., Śleszyński W., Repatriacje i migracje ludności pogranicza w XX wieku. Stan badań oraz źródła do dziejów pogranicza polsko-litewsko-białoruskiego, Białystok 2004

Łatyszonek O., Białoruskie formacje wojskowe 1917-1923, Białystok 1995

Michaluk D. [oprac.], „Jestem przyjacielem Białorusinów..” - raporty wywiadowcze Romualda Ziemkiewicza do II Oddziału Sztabu Generalnego WP z lat 1922-1923, cz. 1 i 2, „Białoruskie Zeszyty Historyczne" 25 (2005), z. 26 (2006)

Michaluk D., Białoruska Republika Ludowa 1918-1920. U podstaw białoruskiej państwowości, Toruń 2010

Mironowicz E., Białoruś, wyd. 1: Warszawa 1999, wyd. 2 uzup.: Warszawa 2007

Misiuk A., Policja Państwowa 1919-1939, Warszawa 1996

Paszkiewicz A., Białoruska reprezentacja w parlamencie II Rzeczypospolitej pierwszej kadencji (1922-1927), „Przegląd Wschodni” 9 (2004), z. 3

Śleszyński W. [wybór i oprac.], Walka instytucji państwowych z białoruska działalnością dywersyjna 1920-1925, Białystok 2005

Zachariasz S., Józef Łohinowicz, „Z Pola walki” 1961, nr 3

Чарнякевіч, А., Постаці беларускага нацыянальнага руху ў Гродне 1909-1939: біяграббічны даведнік, Мінск 2003

Joanna Gierowska-Kałłaur, dr hab., profesor IH PAN, pracownik Zakładu Historii Europy Wschodniej i Studiów nad Imperiami XIX i XX wieku, specjalizuje się w wyszukiwaniu i edycji źródeł, autorka m.in. trzech książek poświęconych Zarządowi Cywilnemu Ziem Wschodnich (1919-1920) i Straży Kresowej (1918-1920); jest również wykładowcą Studium Europy Wschodniej Uniwersytetu Warszawskiego; obecnie pracuje m.in. nad „Bardzo krótkim zarysem zagadnienia białorosyjskiego", opartym głównie na niepublikowanych materiałach archiwalnych ze zbiorów Naczelnego Dowództwa Wojsk Polskich w Fondzie Trofiejnym w Moskwie (j.gierowska-kallaur@uw.edu.pl). 